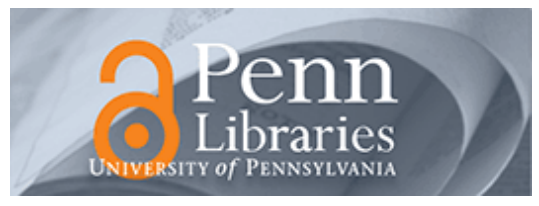

University of Pennsylvania ScholarlyCommons

Finance Papers

Wharton Faculty Research

6-2014

\title{
Borrowing Constraints During the Housing Bubble
}

Irina Barakova

Paul S. Calem

Federal Reserve Bank of Philadelphia

Susan M. Wachter

University of Pennsylvania

Follow this and additional works at: https://repository.upenn.edu/fnce_papers

Part of the Finance and Financial Management Commons, and the Real Estate Commons

\section{Recommended Citation}

Barakova, I., Calem, P. S., \& Wachter, S. M. (2014). Borrowing Constraints During the Housing Bubble. Journal of Housing Economics, 24 4-20. http://dx.doi.org/10.1016/j.jhe.2014.01.001

This paper is posted at ScholarlyCommons. https://repository.upenn.edu/fnce_papers/216

For more information, please contact repository@pobox.upenn.edu. 


\title{
Borrowing Constraints During the Housing Bubble
}

\begin{abstract}
The impact of borrowing constraints on homeownership has been well established in the literature. Wealth is most likely to restrict homeownership followed by credit and income. Using recent movers from the 1979 National Longitudinal Survey of Youth and borrowing constraint definitions commonly used in the literature, we examine the impact of these constraints on the probability of homeownership during the housing market boom between 2003 and 2007. We show that whereas the pool of financially constrained households expanded, the marginal impact of borrowing constraints associated with income and credit quality declined during this period. The constraint associated with wealth, however, continued to have a negative impact on homeownership status, all else equal. The fact that lending standards became less strict is accepted; however the impact of this on homeownership has not been previously studied. Here we find that less restrictive underwriting does appear to have reduced the impact of income and credit quality on homeownership but the impact of the wealth constraint persists.
\end{abstract}

\section{Keywords}

tenure choice, borrowing constraint, credit constraint, mortgage supply, homeownership, credit bubble

Disciplines

Finance and Financial Management | Real Estate 


\title{
Borrowing Constraints during the Housing Bubble*
}

\author{
Irina Barakova ${ }^{\dagger}$, Paul S. Calem ${ }^{\dagger}$, Susan M. Wachter ${ }^{\S}$
}

December 20, 2013

Draft: Not for citation without permission of the authors

\begin{abstract}
The impact of borrowing constraints on homeownership has been well established in the literature. Wealth is most likely to restrict homeownership followed by credit and income. Using recent movers from the 1979 National Longitudinal Survey of Youth and borrowing constraint definitions commonly used in the literature, we examine the impact of these constraints on the probability of homeownership during the housing market boom between 2003 and 2007. We show that whereas the pool of financially constrained households expanded, the marginal impact of borrowing constraints associated with income and credit quality declined during this period. The constraint associated with wealth, however, continued to have a negative impact on homeownership status, all else equal. The fact that lending standards became less strict is accepted; however the impact of this on homeownership has not been previously studied. Here we find that less restrictive underwriting does appear to have reduced the impact of income and credit quality on homeownership but the impact of the wealth constraint persists.
\end{abstract}

JEL Codes: G01 - Financial Crises; G21 - Banks; Depository Institutions; Micro Finance Institutions; Mortgages; G28 - Government Policy and Regulation; R21 - Housing Demand; R31 - Housing Supply and Markets; R38 - Government Policy; Regulatory Policy

Keywords: tenure choice; borrowing constraint; credit constraint; mortgage supply; homeownership; credit bubble

\footnotetext{
* The views expressed in this paper are those of the authors alone, and do not necessarily represent the position of the Office of the Comptroller of the Currency, the Department of the Treasury, the Federal Reserve Bank of Philadelphia or the Federal Reserve System. We thank Darryl Getter and Don Haurin for providing insightful feedbacks and comments on earlier drafts of this paper. We are grateful to Arthur Acoca-Pidolle and Francesco Vercelli, who provided excellent research assistance. Dr. Wachter acknowledges the assistance from the Research Sponsors Program of the Zell/Lurie Real Estate Center at Wharton.

${ }^{\dagger}$ Office of the Comptroller of the Currency (OCC), US Treasury Department, irina.barakova@occ.treas.gov

\$Federal Reserve Bank of Philadelphia, paul.calem@phil.frb.org

${ }^{\S}$ Richard B. Worley Professor of Financial Management, The Wharton School, University of Pennsylvania, wachter@wharton.upenn.edu
} 


\section{Introduction}

An extensive literature studying financial barriers to homeownership has developed over the past two decades. This line of research provides ample evidence that down payment and monthly payment requirements, which respectively depend on the household's wealth and income, traditionally have been a factor in tenure status. The research also documents the impact of borrowers' credit quality, a determinant of access to mortgage credit, on tenure status. A second line of research, theoretical and empirical, demonstrates both that loosened mortgage underwriting helped fuel the boom in house prices between 2003 and 2007 and the boom in house prices supported the credit expansion.

What the literature does not identify is the effect of this credit expansion on borrowing constraints, and the effect of changing borrowing constraints on homeownership. In fact, homeownership did not expand after 2004 despite the expansion of credit supply and loosening of traditional credit constraints. Our paper contributes to the literature by being the first to measure the changes in borrowing constraints during the 2003 to 2007 period of rapidly rising house values, and the associated impacts on homeownership. We also consider the relationship of changing borrowing constraints to regional house price appreciation. ${ }^{5}$

We use data from the National Longitudinal Survey of Youth (NLSY) which is comprised of households headed by persons in their 40s, excluding immigrants. As a relatively homogeneous demographic group, these households provide a controlled sample for studying the impact of the evolving housing and credit environment. The survey provides information on the homeownership status and current house values, as well as income, wealth and credit quality of households that allows us to identify those that face potential income, wealth or credit constraints. Within this sample, we focus on households that have recently moved, because these households face an actual tenure choice decision. The timing of the survey provides two important snapshots bounding the boom period: we use the 2004 and 2008 data which reflects tenure choices among households that moved during 2002-2003 and 2006-2007, respectively.

Consistent with prior studies, the three constraint categories of income, wealth, and credit history are found to be associated with reduced likelihood of homeownership among the recent movers in the first wave of the survey. Importantly, however, although the pool of financially constrained households increased during the boom period, as reflected in

\footnotetext{
${ }^{5}$ See "Explaining the Housing Bubble" (Levitin and Wachter, 2012) for a discussion of the timing of the housing bubble as it relates to real estate fundamentals in particular as it relates to rents and interest rates.
} 
comparison across the two snapshots, the marginal impact of borrowing constraints, other than the wealth constraint, declined.

The paper is organized as follows: The next section reviews the relevant literature, section three discusses the data, and section four outlines the methodology. Section five discusses the results, and section six concludes.

\section{Literature Review}

As noted, our paper builds on the well-established literature that documents a significant role of borrowing constraints as a factor in homeownership status, especially among lowincome and minority households. For instance, Haurin et al. $(1996,1997)$ demonstrates that the wealth constraint plays an important role, even after taking into account the endogeneity of wealth in tenure decisions. ${ }^{6}$

The earlier literature examines wealth and income constraints but does not consider the role of borrowing constraints tied to household credit quality. Rosenthal (2002) introduces credit quality in investigating barriers to homeownership by considering the combined impact of all three types of borrowing constraints using the 1998 Survey of Consumer Finance. Barakova et al. (2003) confirms the importance of credit quality and evaluates the relative impact of credit quality on homeownership rates, distinguishing it from wealth and income constraints. The current study extends Calem et al. (2010), which uses information on wealth, income, and credit in the 2004 wave of the National Longitudinal Survey of Youth (NLSY) to demonstrate the effect of wealth, income and credit constraints in accessing homeownership status.

This paper also relates to the recent and expanding literature that considers the relationship of collateral values to house price dynamics. Demyanyk and Van Hemert (2009) argue that less restrictive underwriting standards prior to the mortgage crisis could have been detected but were masked by rapid house-price appreciation. Pavlov and Wachter (2011) investigate the relationship between riskier, mortgage lending instruments with less restrictive underwriting standards and asset market prices and find that the expansion of credit supply through these instruments increases asset prices and magnifies the effects of demand shocks.

Like Pavlov and Wachter (2011), Adelino et al. (2011) agree that higher credit supply induces an increase in asset prices. In particular, they reject the notion that an increase in housing demand loosens financial constraints. On the other hand, Brueckner et al. (2012) find

\footnotetext{
${ }^{6}$ The study arrived at similar findings with and without endogenizing wealth. Similarly, Calem, Firestone, and Wachter (2010) consider potential endogeneity of wealth and income in a study of the impact of financing constraints using NLSY data, and determine the findings to be robust to using instruments.
} 
feedback effects between expectations of rising house prices and less restrictive mortgage underwriting. Coleman et al. (2008) also find that the expansion of credit is a result of the rise in house prices during the boom period.

Another line of investigation uses structural vector error correction models to determine whether mortgage expansion Granger-causes price rises or whether price rises Grangercauses an expansion in mortgage credit in the US and elsewhere. The findings generally support bidirectional causality. (See Anundsen \& Jansen 2012; Berlinghieri, 2010; Oikarinen, 2009a; Oikarinen, 2009b; Sophocles \& Vlassopoulos, 2009; Fitzpatrick \& McQuinn, 2007; Gerlach \& Peng, 2005; Gimeno \& Martinez-Carrascal, 2010; Hoffman, 2004; Hoffman, 2003.)

A related question the literature addresses is whether the rise in house prices is associated with greater reliance on risk-based pricing allowing for lower credit scores, and low- or nodocumentation (low-, no-doc) mortgages (see Getter, 2011). The argument is that when collateral (house) values are rising, lenders do not need to verify income to underwrite a loan but rather can rely primarily on credit scores and price the loan according to the riskiness of the borrower. Based on this analysis, wealth, income and credit constraints reduce the probability of homeownership when house prices do not increase, but when they do increase, risk-based pricing (with the assumption that house values will continue to rise) makes these constraints non-binding. ${ }^{7}$ Our empirical tests allow us to identify whether this applies generally and also for each constraint, separately.

Our paper contributes to both the literature on financing constraints and the research on linkages between credit supply and house prices during the boom. First, the paper documents the impact of the change in borrowing constraints on homeownership in this unusual period. Second, quantifying the impact of borrowing constraints during the boom period helps explain the linkages between credit supply and collateral values.

\section{Data}

We use data from the 1979 National Longitudinal Survey of Youth (NLSY) to study the

\footnotetext{
${ }^{7}$ This is consistent with practices documented in the Federal Reserve interagency guidance on Nontraditional Mortgage Product Risks (Sept. 29, 2006), Final Rule amending Regulation Z (July 14, 2008).The result, according to Getter (2011), is that no-doc lending makes it possible to follow a lifecycle consumption pattern where income is no longer tied to consumption, consistent with the literature on credit constraints to consumption (Zeldes, 1989; Campbell and Cocco, 2003). This possible relationship between house borrowing constraints and consumer welfare outcome is discussed in theoretical general equilibrium models (see Favilukis et al., 2010); see also "Why Housing" (Levitin and Wachter, 2013) for another perspective on this argument.
} 
interaction between borrowing constraints and house price dynamics in determining whether households become homeowners. This survey is conducted every other year across a fixed sample of households. A set of sampling weights is provided (and which we utilize) to adjust for attrition of the sample over time.

We use the 2004 and 2008 waves of the NLSY, which bound the housing boom period of 2004 through 2007 with individual variables described in Table 1. In particular, the 2004 data reflect home purchases mostly in 2002 and 2003, preceding the period of rapid acceleration in home values and expanded availability of nontraditional mortgage products, and the 2008 data reflect purchases mostly in 2006 and 2007, when the use of nontraditional mortgage products and home values peaked.

There are several advantages to using these data in addition to its relevant timing. First, the survey has information for the three major borrowing constraint categories-income, wealth, and credit - for both periods. ${ }^{8}$ Second, the data identify participants that have moved since the prior survey, enabling us to focus on recent movers. Focusing on recent movers mitigates concerns about mismatch between current households' financial condition and original tenure choice. Moreover, recent movers are of particular relevance because these households recently faced an actual tenure choice decision. ${ }^{9}$ In other words, the tenure status of some non-movers may not reflect their current preferences, but they remain in their current status because of transactions costs.

Obviously, the NLSY79 sample is representative only of a specific generational cohort (individuals mostly between 40 and 50 years of age), not of all U.S. households. We do not view this as a significant drawback because our focus is on the evolving impact of borrowing constraints over the boom period, which we expect would be similar for other demographic groups. Indeed, it can be viewed as an advantage to the extent that it allows for such analysis within a relatively controlled sample. ${ }^{10}$

${ }^{8}$ Wealth is defined by the NLSY as net worth-the difference between families' gross assets (Home
Value, Car Value, Cash Saving, IRAs, $401 \mathrm{Ks}$, CDs, Stocks/Bonds, Trusts, Business Assets) and their
liabilities (Mortgage, Property Debt, Business Debt, Car Debt, Other Debt). The data includes an
aggregate net worth field (cleaned and imputed for missing records), which is what we use but also
construct wealth from the individual assets and liabilities similar to Calem et al (2010). For a full
listing of assets and liabilities and imputations,
see https://www.nlsinfo.org/content/cohorts/nlsy79/other-documentation/codebook-supplement.
${ }^{9}$ Even though the National Longitudinal Survey of Youth collects panel data, this is not a panel data
study. A third of the observations are repeat movers in both years. With only a third of the
observations occurring in both years, the sample sizes are much reduced, which will reduce the power
of any test. Making use of the panel aspect of repeat moves would entail major complications, such as
potential endogeneity of the repeat move choice.
${ }^{10}$ An alternative data source for our question is the Survey of Consumer Finances, but the survey does 
Table 2 shows summary statistics for the two samples of recent movers, labeled 2003 and 2007, respectively. We have 1,962 individuals who changed their residence in 2003 and 1,591 individuals who did so in 2007. The mean age is 43 in 2003 and 46 in 2007 for both the full sample and the owners and renters groups (where owning and renting reflect tenure status after the move). A somewhat larger portion is choosing to reside in an MSA (post-move) in 2007 compared to 2003, which is true both for owners and renters. Fewer are married and have children in the 2007 recent mover group than in the 2003 recent mover group. Family $\log$ income does not change significantly between 2003 and 2007. Renters in both years have lower wealth and somewhat lower income than owners. Mean house value is unchanged between 2003 and 2007.

In these recent mover samples, the homeownership rate decreases from 47 to 39 percent between 2003 and 2007. ${ }^{11}$ This drop in homeownership for recent movers in the NLSY is consistent with the national trends reported by the U.S. Census, which show declining homeownership since 2004, as shown in Figure 1. In particular, the Census reports a national decrease in homeownership for ages $40-49$ from $69 \%$ to $67 \%$.

Table 2 also provides the same set of summary statistics for the full survey data of over 7,000 observations in both years. The statistics are similar to those reported for the recent mover samples, but non-movers are more likely to be married, to have children at home, to have a larger family size and higher average house value and wealth.

Two measures of local housing market conditions are used in this study. We measure local house price appreciation rates using the FHFA all-transactions house price index at the MSA level, or the index for the non-MSA part of the states for households residing outside MSAs. ${ }^{12}$ We also use a value-to-rent ratio based on American Community Survey median house value and median gross rent for the MSA or state in which the respondent resides.

Figure 2 shows the aggregate change in house prices from 2000 to 2007. Comparison to Figure 1 indicates that homeownership rates peaked in 2004 before house prices peaked in

not identify location of households. We do however use the SCF data to replicate our tests to the extent possible. Similarly, the American Housing Survey contains representative homeownership data but lacks information on wealth.

${ }^{11}$ The aging of the NLSY population is unlikely a factor influencing this decline in the homeownership rate, because across households in the sample age has a slight positive correlation with likelihood of ownership in the NLSY sample (4.5\% in 2003 and $2 \%$ in 2007).

${ }^{12}$ We use the FHFA all-transactions house price index, which is based on sales as well as appraisals for refinance. The reason is that the purchase-only index is available only for the 100 largest MSAs and at state level, whereas the all-transaction is available for all MSAs as well as for non-MSA parts of the states. Results were found to be robust to substituting the purchase-only index where available. 
2006 and declined more sharply thereafter. Figure 3 shows how the change in the FHFA index is distributed across MSAs for the two periods 2000 to 2003 and 2004 to 2007.

\section{Methodology}

Following an established methodology in the literature, we jointly estimate a (first-stage) selection equation identifying homeowner households that are not subject to borrowing constraints, and a (second-stage) housing demand equation indicating the preferred home value of these unconstrained, owner households. We then apply the estimated, target home value equation to the entire (renter and owner) recent mover population to distinguish borrowing constrained households. In essence, this approach assumes that a household that is relocating and considering ownership, if not financing constrained, would demand the same value home as a similarly situated, unconstrained owner household in the general population.

Three conditions must be satisfied for a household to be considered unconstrained. First, their wealth must exceed 5\% of their targeted house value, implying an ability to make a 5 percent down payment. Second, the mortgage payment associated with borrowing 95 percent of the targeted house value, given the prevailing market interest rate ${ }^{13}$ for a fixed-rate mortgage plus the typical premium for private mortgage insurance, must not exceed $28 \%$ of their monthly income, implying ability to meet the traditional, standard requirement for prime mortgage credit. We also consider alternative thresholds of higher down payment and payment-to-income ratios for robustness including 10\% down payment and 33\% payment-toincome. Third, they must have favorable credit records with respect to having none of the following risk indicators: a credit line that is fully drawn, a credit request refusal in the last 5 years, or bankruptcy in the last 9 years; and they are not "thin file", meaning they have current or previous credit utilization. These are important indicators of consumer credit risk and major components of the consumer's credit score, which is driven by length of credit history, past delinquencies, amount owed and utilization. ${ }^{14}$ Note that although we do not have actual mortgage terms in the data, the intention of defining constraints under traditional standards is to capture whether alternative products and risk based pricing have relaxed the traditional constraints, that is, whether the probability of homeownership has increased and the impact of the traditional constraints has lessened with the growth of alternative products and risk based pricing.

The housing demand equation is estimated within the group of unconstrained

\footnotetext{
13 The interest rate is the minimum weekly Primary Mortgage Market Survey rate for $2003(5.21 \%)$ and 2007 (5.96\%.) from http://www.freddiemac.com/pmms/pmms_archives.html.

${ }^{14}$ See Calem et al. 2010 for further discussion of the measurement of credit quality.
} 
homeowners and relates a household's home value to household income, demographic variables, and geographic location. ${ }^{15}$ Unconstrained homeowners are those whose home value, wealth, and income satisfy the specified thresholds, and who have good credit. As membership in this group is not a random event, we control for sample selection by applying the Heckman two-step selection equation. Accordingly, we first estimate an equation for probability of being an unconstrained homeowner, from which we obtain an adjustment for sample selection that is applied in our housing demand equation.

We follow Calem et al. (2010) in constructing the specification for the jointly estimated selection model and unconstrained housing demand model, equations (1). The same variables are used in both equations since we did not find predictors of unconstrained homeowners not related to the house value. ${ }^{16}$

$$
\begin{aligned}
& \log \left(\text { house value }\left.\right|_{i} \mid \text { unconstrained }\right)=f\left(\log \left(\text { inc }_{i}, \text { married }_{i}, \text { size }_{i}, \text { location }_{i}\right)\right. \\
& \text { selection model: } \text { unconstrained }=f\left(\log (\text { inc })_{i}, \text { married }_{i}, \text { size }_{i}, \text { location }_{i}\right)
\end{aligned}
$$

After applying the estimated housing demand equation to distinguish constrained from unconstrained households for the full population of owners and renters, we estimate a probit model of homeownership likelihood in relation to the borrowing constraints, equation (2). As noted earlier, the probit model estimation is restricted to households that were recent movers, as their tenure decision is a direct outcome of the move.

$$
\text { owner }_{i}=f\left(\log \left(\text { inc }_{i}, \text { constraints }_{i}, \text { HPI change, } \text { married }_{i}, \text { race }_{i}, \text { education }_{i}, \text { kids }_{i}\right)\right.
$$

Controls include race, marital status, whether the respondent has children, and the respondent's education level.

The models are estimated for both 2003 and 2007 in order to assess changes associated with the housing market boom during the interim period. In addition to exploring the direct relationship between homeownership outcomes and borrowing constraints at the beginning

\footnotetext{
${ }^{15}$ US Census region is the most disaggregated geographic information generally available to the public from the NLSY data. For this study, we obtained access to the confidential MSA-level geographic identifier; such access is granted to academic institutions subject to certain qualifications.

${ }^{16}$ See, for example, Haurin, Hendershott, and Wachter (1996) for discussion of the bivariate probit model in a housing demand and tenure choice context. With bivariate probit, identification is possible even with a common set of explanatory variables due to the non-linearity of the probit model.
} 
and end of the boom period, we look at tenure choice in relation to local house price appreciation and, in an alternative specification, in relation to value-to-rent ratios. The rapid rise in home values in many regions that characterized the boom period between 2003 and 2007 may have positively influenced homeownership through the impact on households' expected asset returns from ownership, since housing is both an investment and consumption good. At the same time, rapidly rising house prices or value-to-rent ratios could generate concerns about overpricing and imminent declines in value or could affect homeownership outcomes directly through the relative costs of renting versus owning or indirectly through their impact on borrowing constraints or on other aspects of affordability.

\section{Results}

We first report the results, in Table 3, from the two-equation model (1) of housing demand of unconstrained owner households. This model determines a household's preferred (target) house price in the absence of borrowing constraints, in relation to household location and demographic characteristics. ${ }^{17}$ The model is estimated on the entire homeowner population, consisting of 6,130 observations in 2003 and 6,084 observations in 2007.

From the house price equation we see that in both years, the regions that comprise the East, West, and South Central regions in the US are associated with lower house prices and the three large MSAs, Boston, New York, and Washington DC are associated with higher house prices. Larger families are associated with higher house values, but controlling for household size, marital status is associated with a lower house value. ${ }^{18}$

Table 4 reports the percentages of borrowing constrained households among recent movers, by sample period and by type of borrowing constraint, using the traditional measures. We compare the percent constrained by wealth, income, credit, or all constraints combined in 2007 relative to 2003. More recent movers were wealth constrained in 2007 (52\%) than in 2003 (44\%). There is a similar increase in the percent income constrained. The percent that are indicated to be credit constrained increases slightly. The percent with at least one constraint and all three constraints also increases between 2003 and 2007, based on the

\footnotetext{
${ }^{17}$ The same set of variables is used in the house price and the unconstrained household selection equations, as in Calem et al. (2010). Some demographic variables that were used are not reported in Table 3 for the sake of brevity, as they were not statistically significant in either equation.

${ }^{18} \mathrm{We}$ find that the impact of marital status on preferred house value is more weakly negative (estimated coefficient of -0.14) and offset by the relationship to household size when the housing demand equation is estimated for the full homeowner population (both financially constrained and unconstrained.) A possible explanation for the large, negative relationship of married status for unconstrained households is that unmarried households in this age cohort have a strong preference for residing in central city locations.
} 
traditional measures. ${ }^{19}$ We note a high correlation between the income and wealth constraints of close to $40 \%$ and only around $10 \%$ correlation between being credit constrained and each of the other two.

The substantial increase in the proportion of recent movers that are wealth and income constrained using traditional measures is likely tied to the rise in house prices in this period. That rising prices will cause income constraints to be more binding on a household seeking to relocate is clear; however, the impact on wealth constraints is more nuanced. Whereas house price appreciation provides a wealth benefit to homeowners seeking to relocate from areas with rapidly increasing prices to those with slower price appreciation, those relocating in the other direction will be increasingly wealth constrained according to the traditional criterion. Likewise, owners seeking to "trade-up" into a higher-priced home, along with renters, may increasingly be wealth constrained as a result of rising house prices. Thus, a plausible explanation for the increase in proportion of wealth constrained households among recent movers is that the latter effects of rising prices were predominant. Note that less restrictive underwriting would not affect the proportion constrained by these measures, which assume traditional underwriting. However, less restrictive underwriting should be reflected in a weaker impact of the financing constraints on homeownership in the estimation of the probit model.

\section{a. Probit Model}

Tables 5 and 6 report the estimation results for probability of homeownership in relation to the three borrowing constraint indicators. Table 5 provides estimated coefficients and standard errors and Table 6 reports the marginal effects corresponding to the results in Table 5, for four specifications. Model A1 (column 1) omits the housing market variables, while models A2 and A3 (columns 2 and 3) include the change in HPI and the value-to-rent ratio respectively and model A4 include both variables (column 4).

Across all four specifications, we see a substantial decrease in the effect of income and credit constraints between 2003 and 2007. In 2007 we no longer see coefficients that are significantly different from zero for income and credit constraints. The wealth constraint effect also declines in magnitude, although it is still significant and negative. In 2003 all constraints have a significant negative sign with the wealth constraint having the largest effect followed by income and credit. In 2007, only the wealth constraint remains statistically significant.

\footnotetext{
${ }^{19}$ The percent non-constrained, although higher for homeowners in both years, decreases more for owners than for renters.
} 
The weakened impact of credit constraints is consistent with less restrictive underwriting that broadened availability of credit to borrowers with weaker credit records, and thus is consistent with expansion of subprime lending during this period. Subprime credit also may have contributed to weakened income constraints by de-emphasizing traditional payment-toincome ratio requirements. In addition, the weakened impact of income constraints is consistent with expanded supply of non-traditional products that offered deferred repayment of principal or interest, including interest only mortgages, pay-option adjustable rate mortgages, and ARMs with introductory "teaser" interest rates.

The persistent impact of wealth constraints is somewhat unexpected given the growth in high-LTV borrowing during this period in the form of simultaneous first and second liens (“piggyback loans"), as documented by Avery, Brevoort, and Canner (2006, 2007). Many such piggybacks had a combined LTV of 100 percent, typically split between an 80 percent first lien and 20 percent second (so-called 80-20's). One would expect the expansion of piggyback lending to have made wealth constraints less binding. Nonetheless rising house prices could counteract the impact of this expansion of piggyback lending on the impact of wealth constraints. In our discussion subsection below, we provide some interpretations of the observed persistence of wealth constraints within this context.

Table 5 also shows a statistically significant negative association between homeownership and the value-to-rent ratio (model A3) for both 2003 and 2007, with a similar magnitude in both years. This result is consistent with the literature that links value-to-rent ratios to the relative cost of homeownership or it could reflect expected mean reversion of housing prices. House price appreciation over the past three years is negatively associated with homeownership in 2003 but insignificant in 2007 and is insignificant in both years when value-to-rent is included (model A4).

Other variables included in the regressions as controls also show shifting coefficients across these two periods. Of greatest interest perhaps are the rising negative coefficients for minority status. Over this period minorities become less likely to choose homeownership, all else equal. This may be due to omitted variables in the measurement of constraints across race and ethnicity, magnified by rising house prices.

We estimate the tenure choice equation for both years with interactions of the constraint variables with an indicator for African-American households and we separately estimate the tenure choice equation for African-American households. We do not observe any material differences in the impact of constraints across race categories over time. However, the coefficient on the wealth constraint variable is larger for both years for African-American households. ${ }^{20}$

\footnotetext{
${ }^{20} \mathrm{We}$ also replicated the base model using SCF data. Without geography we find it is difficult to
} 


\section{b. Model Extensions}

We re-estimate these equations under a variety of alternative assumptions. We begin by varying the down payment and payment-to-income ratios that respectively define the wealth and income constraints in Table 7. The results are robust to alternative, a wealth constraint threshold of 10 percent down payment. The results are also robust to an alternative income constraint threshold of 30 and 33 percent payment-to-income ratios. ${ }^{21}$

We also combine all three of our constraints and compare the response of recent movers to whether they are constrained by any of the three between 2003 and 2007. These results are shown in Table 8 for three specifications. We find that the status of being constrained by any of the measured constraints decreases the probability of homeownership in both periods, and, although the coefficient on the constraint decreases in size, this decline is not statistically significant. Results are robust to alternative models with interactions on the constraint. ${ }^{22}$

In addition, because preferences and other unobserved factors may vary significantly between recent movers that were previously owners and those that were previously renters, we repeat the baseline analysis separately for these two cohorts. Results are reported in Table 9. The estimated relationships are similar across the two cohorts and align with those observed for the combined population. One difference, however, when the regressions are estimated by cohort, is that the coefficient of value-to-rent ratio is larger in absolute value for previous renters and statistically significant only for this cohort. This may reflect a stronger revealed preference for ownership among previous owners which causes them to be less sensitive to changes in the relative cost of owning to renting as measured by this ratio.

These results may be biased due to sample selection. For example, there may be biases in the 2007 sample if the movers included in the 2003 estimates are removed for 2007 - if perhaps, those that could move, did, under more-constrained criteria in 2003, while those that could not move in 2003, but could move, and did, under less-constrained conditions in 2007. The controls in the model should account for a portion of this, but there remains a possibility of unknown characteristics that make the 2003 and 2007 samples different. We test for possible selection bias associated with recent movers by estimating a Heckman bivariate probit model for which the first stage estimates the likelihood of moving and the second stage

identify target house values, thus, although the results (which are available from the authors) are supportive of the findings here, we do not include them.

${ }^{21}$ We also replicate the instrumental variable models used in Calem et al. (2010), using instruments for income and wealth to define the income and wealth constraints. The decrease in the impact of the credit constraint between 2007 and 2003 remains the same.

${ }^{22}$ In one model we control for "only income constrained", "only credit constrained", "income or wealth constraint" and "all other constrained." In the other we control for each of the constraints individually and with interactions of credit with wealth and credit with income. 
predicts the likelihood of homeownership likelihood. The estimated relationships of ownership status to the constraint indicators for both years are essentially unchanged. ${ }^{23}$

Finally, we test for whether the impact of credit constraints varies with housing market conditions by including interaction of the constraint indicators with an indicator of significant house price increase. We apply the $80^{\text {th }}$ percentile of three-year house price appreciation to distinguish high appreciation areas, as well as alternative thresholds. ${ }^{24}$ We do this to test for whether greater relaxation of borrowing constraints is associated with high-appreciation areas. Tables 10 and 11 show results for three alternative specifications (models B1, B2, and B3) analogous to models A1, A2, and A3 in Tables 5 and 6, distinguished by choice of variable to measure housing market conditions. Table 10 provides estimated coefficients and standard errors and Table 11 reports the marginal effects corresponding to the results in Table 10.

We find that the credit quality constraint does not have a significant impact on homeownership in areas with high rates of house price appreciation in 2003, and by 2007 , this variable is not statistically significant in either price appreciation category. The declining impact of the income constraint and relatively stability of the wealth constraint appears to be robust across the two price appreciation categories. We also interact constraints with the value-to-rent ratio with similar results.

These findings are broadly consistent with the earlier results without interaction terms. However, the interaction effects for the credit quality constraint may provide some additional insight on evolution of lending practices in this period as discussed below.

\section{c. Discussion}

Overall, the model and its extensions establish the persistent significant impact of the wealth constraint and the declining impact of income and credit quality constraints during the bubble years. These findings are consistent with relaxation of credit standards between 2003 and 2007, along with the expanded supply of subprime, alt A, and other non-traditional credit products. These may have largely eliminated income and credit barriers affecting households'

\footnotetext{
${ }^{23}$ The first stage, mover equation includes the same explanatory variables as the homeownership equation plus a few others: prior ownership status (ownership status as of the 2002 and 2006 waves of the survey for the 2003 and 2007 samples, respectively); an indicator for having moved in the prior two years (during 2000-2001 for the 2003 sample, and during 2004-2005 for the 2007 sample); and an indicator for divorce. Estimation output from the bivariate probit estimation is available from the authors on request.

${ }^{24}$ We report only results based on the $80^{\text {th }}$ percentile threshold. We also applied a $25 \%$ increase in prices as the threshold (which corresponds to the $80^{\text {th }}$ percentile in the 2000 to 2003 period), and obtained similar findings.
} 
ability to finance the purchase of a target valued home.

Despite the measured decreasing impact of credit quality and income constraints, homeownership does not increase when comparing recent movers in 2003 to recent movers in 2007. In fact, there is a slight decrease in homeownership among movers, as in the general population over this period. The decline in homeownership in our sample may be explained by the increase in the percent who are constrained; the persistent impact of the wealth constraint; and the rising value-to-rent ratio.

The fact that the wealth constraint holds while the credit and income constraints weaken is consistent with lenders relying on collateral while easing other underwriting criteria. This result is agnostic as to whether rising house prices enabled greater reliance on collateral or whether relaxed credit constraints contributed to rising prices.

Even with greater reliance by lenders on collateral when easing other underwriting criteria, the persistence of the wealth constraint may seem surprising, since during this period as we have noted earlier, high-LTV "piggyback" lending, up to 100 percent combined LTV, became increasingly common. ${ }^{25}$ Nevertheless, we can think of several additional reasons why the wealth constraint could remain binding. First, as described by Avery, Brevoort, and Canner (2006, 2007), a substantial proportion of the piggyback loans originated during this period were merely replacing first-lien loans with mortgage insurance which for many years had been a source of high-LTV financing. The piggybacks gained popularity as a lower cost (lower monthly payment) alternative to mortgage insurance, and as such would have contributed to reducing income constraints but not wealth constraints. Second, a substantial proportion of piggybacks were originated in the subprime market, expanding the availability of subprime credit, and thus helping to ease income and credit constraints. Third, even with 100 percent financing of the purchase price there still would be closing costs, moving costs, and fix-up costs for which the borrower would need disposable wealth.

Moreover, mitigating effects of piggyback lending on wealth constraints could have been offset by exacerbating effects of rapidly rising house prices. Such exacerbating factors include higher costs of a high LTV loan (which, in the case of a first and second lien would have a relatively high blended rate due to risk-based pricing. In addition, in an environment of rapidly appreciating house values, the asking price for the home might be higher than the appraised value, used to underwrite the loan, requiring the borrower to come up with the cash to close this "appraisal gap." Indeed, one might conclude that the surprising finding is not continued persistence of wealth constraints, but the banishment of income constraints despite

\footnotetext{
${ }^{25}$ Some non-regulated non depository institutions did make second liens available which raised the CLTV up to $125 \%$ but such loans were not generally available and did not become common.
} 
the rapid house price appreciation, which attests to the effectiveness of alternative mortgage products and less restrictive underwriting standards in mitigating income constraints.

We cannot identify the extent to which each of these potential mechanisms contributed to persistent wealth constraints. Nonetheless, this constraint holds and discourages homeownership in 2003 and in the height of the bubble in 2007. Even with risk based pricing eliminating the impact of credit and income constraints, it does not appear that the shift to risk based pricing eliminates the impact of a collateral based wealth constraint. This constraint on homeownership remains binding in a period of risk based pricing and less restrictive underwriting conditions. This result combined with the rise in the value-to-rent ratio can help to explain the decline in homeownership that occurred in these years.

Our results also shed some light on the association between house price appreciation and relaxation of borrowing constraints. In the 2003 sample, subprime credit appears to have been more readily available where collateral values were appreciating while by 2007 we observe a general removal of credit quality and income constraints to homeownership that appears to be independent of geography and local price appreciation dynamics. However, we do not observe an association between house price appreciation and the impact of income constraints in 2003. This is consistent with the rapid growth of alt-A, interest only, and other nontraditional mortgage products aimed at increased affordability, only after 2003.

As of 2007, we observe a general removal of credit quality and income constraints independent of geography or areas of relatively high price appreciation. This suggests that marginal impacts of local house price appreciation on credit supply had a secondary impact during the bubble years, consistent with broad expansion of mortgage credit independent of geography. ${ }^{26}$

\section{Conclusions}

This paper examines the evolution of borrowing constraints during the 2003 to 2007 period of rapidly rising house values, using data from the National Longitudinal Survey of Youth (NLSY). Use of the NLSY sample focuses the analysis on households in their 40s, excluding young individuals and immigrants. However, we do not view this as a significant drawback because our focus is on the evolving impact of borrowing constraints over the boom period and their interaction with local housing market conditions, which we expect would be similar for other demographic groups. Moreover, the NLSY sample of individuals

\footnotetext{
${ }^{26}$ One possible explanation is the predominance of rapid house price growth during this period combined with the fact that mortgages from weaker housing markets could be packaged into MBS together with mortgages from markets with strong house price appreciation.
} 
is likely less financially constrained than the excluded household categories, so any impact of constraints could be larger for the broader population.

Consistent with prior studies, the three constraint categories income, wealth, and credit quality are associated with reduced likelihood of homeownership among the recent movers in the 2003 wave of the NLSY, but only the impact of the wealth constraint persists in 2007. These findings suggest that easing of lending standards during the boom period had a mitigating impact on income, and credit quality constraints to homeownership but not on the wealth constraint. Higher prices interacted with less strict underwriting standards so that wealth constraints were still an obstacle to homeownership.

Persistence of the wealth constraint may help explain why the homeownership rate declined during the boom period. The general increase in the proportion of borrowing constrained households consequent to rising house prices and the rise in the value-to-rent ratio could have further curtailed homeownership.

In the 2003 sample, we observe easing of the credit quality constraint in areas with relatively rapid house price appreciation, consistent with other studies that have found an association between rising house prices and less restrictive underwriting. As of 2007, we observe a general removal of credit quality and income constraints independent of geography, consistent with broad expansion of subprime and non-traditional mortgage credit. 


\section{References}

Adelino, M., Schoar, A., and Severino, F. (2011). Credit Supply and House Prices: Evidence from Mortgage Market Segmentation.

http://papers.ssrn.com/sol3/papers.cfm?abstract_id=1787252

Anundsen, A. K. and Eilev S. Jansen. (Forthcoming). Self-reinforcing effects between housing prices and credit. Journal of Housing Economics.

Avery, B., Brevoort, K., Canner, G. (2007). The 2006 HMDA data. Federal Reserve Board 93(1), A123-A166.

Avery, B., Brevoort, K., Canner, G. (2006). Higher-priced home lending and the 2005 HMDA data. Federal Reserve Board 92(3), A123-A166.

Barakova, I., Bostic, R. W., Calem, P. S., and Wachter, S. M. (2003). Does credit quality matter for homeownership? Journal of Housing Economics, 12(4):318-336.

Berlinghieri, L. (2012). Essays on House Price Fluctuations in the U.S., Ph.D. thesis, University of Washington .

Brueckner, J., Calem, P., and Nakamura, L. (2012). Subprime mortgages and the housing bubble. Journal of Urban Economics, 17(2):230-243.

Calem, P. S., Firestone, S., and Wachter, S. M. (2010). Credit impairment and housing tenure status. Journal of Housing Economics, 19(3):219-232.

Campbell, J. Y. and Cocco, J. F. (2003). Household risk management and optimal mortgage choice. The Quarterly Journal of Economics, 118:1449-1494.

Coleman, M., LaCour-Little, M., and Vandell, K. (2008). Subprime lending and the housing bubble: Tail wags dog? Journal of Housing Economics, 17:272-290.

Demyanyk, Y. and Van Hemert, O. (2009). Understanding the Subprime Mortgage Crisis. The Review of Financial Studies, 24(6):1848-1880.

Favilukis, J., Ludvigson, S. C., and Van Nieuwerburgh, S. (2010). The macroeconomic effects of housing wealth, housing finance, and limited risk-sharing in general equilibrium.

Fitzpatrick, T. and McQuinn, K. (2007). House Prices and Mortgage Credit: Empirical Evidence for Ireland. The Manchester School. 75:82-103.

Gerlach, S. and Peng, W. (2005). Bank Lending and Property Prices in Hong Kong. Journal of Banking and Finance. 29:461-481.

Getter, D. E. (2011). Nontraditional Mortgage Products: Innovative or Toxic? In Consumer Knowledge and Financial Decisions: Lifespan Perspectives., pages 183-196. D.J. Lamdin (ed.), Springer: International Series on Consumer Science.

Gimeno, R. and Martinez-Carrascal, C. (2010). The relationship between house prices and house purchase loans: The Spanish case. Journal of Banking and Finance. 34:1849-1855.

Haurin, D. R., Hendershott, P. H., and Wachter, S. M. (1996). Wealth accumulation and housing choices of young households: an exploratory investigation. Journal of Housing Research, 7(1):33-57. 
Haurin, D. R., Hendershott, P. H., and Wachter, S. M. (1997). Borrowing constraints and the tenure choice of young households. Journal of Housing Research, 8(2):137-154.

Hoffman, B. (2003). Bank lending and property prices: Some international evidence. The Hong Kong Institute for Monetary Research.

Hoffman, B. (2004). The determinants of private sector credit in industrialised countries: Do property prices matter. International Finance. 7:203-234.

Levitin, A. J. and Wachter, S. M. (2012). Explaining the housing Bubble. Georgetown Law Review. 100(4):1177-1258.

Levitin, A.J. and Wachter, S.M. (2013). Why Housing? Housing and Policy Debate, 23(1): 527.

Oikarinen, E. (2009). Household Borrowing and Metropolitan Housing Price Dynamics: Empirical Evidence from Helsinki. Journal of Housing Economics, 18(2):126-139.

Oikarinen, E. (2009). Interaction between housing prices and household borrowing: The Finnish case. Journal of Banking and Finance. 33:747-756.

Pavlov, A. and Wachter, S. M. (2011). Subprime Lending and Real Estate

Prices. Real Estate Economics, 39(1):1-17.

Rosenthal, S. S. (2002). Eliminating credit barriers: how far can we go? In Low-income homeownership: Examining the unexamined goal. Retsinas, N.P. (Ed.).

Zeldes, S. P. (1989). Consumption and liquidity constraints: An empirical investigation. Journal of Political Economy, 97 (21):305-346. 
Table 1: Variables Description

\begin{tabular}{|c|c|c|}
\hline Variable & Definition & Source \\
\hline \multicolumn{3}{|l|}{$\begin{array}{l}\text { Household } \\
\text { Characteristics }\end{array}$} \\
\hline Log Income & log of total family income in last calendar year: 2003: r8496100, 2008: t2210000 & NLSY \\
\hline Log Family Size & family size: 2004: r8496000, 2008: t2209900 & NLSY \\
\hline Married & marital status : 2204: r8496600, 2008: t2210400 & NLSY \\
\hline Black & race of respondent: r0810100 & NLSY \\
\hline Hispanic & ethnicity of respondent : r7093000 & NLSY \\
\hline $\begin{array}{l}\text { Log Grade } \\
\text { Attained }\end{array}$ & log of highest grade completed by respondent: 2004: r8497000, 2008: t2210700 & NLSY \\
\hline Kids & there are children in household : 2004: R8504300, 2008: T2217800 & NLSY \\
\hline \multicolumn{3}{|l|}{ Location } \\
\hline In MSA & respondent currently resides in a Metropolitan Statistical Area: 2004: R8498700, 2008: T2212300 & NLSY \\
\hline Regions & $\begin{array}{l}\text { regional division as defined by the US census: California or Hawaii, Pacific (Alaska, Oregon, } \\
\text { Washington), East North Central, East South Central, Mid Atlantic, Mountain, New England, South } \\
\text { Atlantic Region, West North Central, West South Central }\end{array}$ & US Census \\
\hline MSAs & Metropolitan Statistical Areas in which the respondent resides: Boston, New York, Washington DC & NLSY \\
\hline \multicolumn{3}{|l|}{ Market Values } \\
\hline Change HPI & $\begin{array}{l}\text { percent change in the FHFA house price index for the MSA or state in which the respondent resides as } \\
\text { of } 2004 \text { or } 2008 \text {, using FHFA all- transaction indexes for MSAs and state non metropolitan areas. }\end{array}$ & FHFA \\
\hline Value to Rent & $\begin{array}{l}\text { median house value divided by the median annual rent for the MSA or state in which the respondent } \\
\text { resides }\end{array}$ & $\begin{array}{l}\text { US Census } \\
(\mathrm{ACS})\end{array}$ \\
\hline incr HPI & $\begin{array}{l}\text { MSA whose house price increase during the period ( } 2000-2003 \text { and 2004-2007) place them above the } \\
\text { 80th percentile of the distribution according to FHFA House price Index }\end{array}$ & NLSY \\
\hline non-incr HPI & $\begin{array}{l}\text { MSA whose house price increase during the period (2000-2003 and 2004-2007) place them below the } \\
80^{\text {th }} \text { percentile of the distribution according to FHFA House Price Index or non -MSA areas }\end{array}$ & NLSY \\
\hline \multicolumn{3}{|l|}{ Constraints } \\
\hline $\begin{array}{l}\text { Wealth } \\
\text { Constraint }\end{array}$ & respondents whose wealth is inferior to $5 \%$ of their optimal house value & NLSY \\
\hline $\begin{array}{l}\text { Income } \\
\text { Constraint }\end{array}$ & $\begin{array}{l}\text { respondents who would have to spend more than } 28 \% \text { of their annual income on a mortgage } \\
\text { corresponding to } 95 \% \text { of their optimal house value based on minimal weekly interest rates from Freddie } \\
\text { Mac Primary Mortgage Market. }\end{array}$ & $\begin{array}{l}\text { NLSY, } \\
\text { Freddie } \\
\text { Mac }\end{array}$ \\
\hline Credit Constraint & $\begin{array}{l}\text { respondents who are deemed to have high credit risk because of a credit line that is fully drawn (2004: } \\
\text { r8417600, 2008: t2181900); a credit request refusal in the last } 5 \text { years (2004: r8418300, 2008: } \\
\text { t2182301); or bankruptcy in the last } 9 \text { years (2004: r8418001, 2008: t2182301). Or who are considered } \\
\text { as thin- file because they do not report previous credit utilization. }\end{array}$ & NLSY \\
\hline $\begin{array}{l}\text { Income Constr* } \\
\text { incr HPI }\end{array}$ & interaction of the income constraint and increasing HPI variables & \\
\hline $\begin{array}{l}\text { Income Constr* } \\
\text { non-incr HPI }\end{array}$ & interaction of the income constraint and non -increasing HPI variables & \\
\hline $\begin{array}{l}\text { Wealth Constr* } \\
\text { incr HPI }\end{array}$ & interaction of the wealth constraint and increasing HPI variables & \\
\hline $\begin{array}{l}\text { Wealth Constr* } \\
\text { non-incr HPI }\end{array}$ & interaction of the wealth constraint and non -increasing HPI variables & \\
\hline $\begin{array}{l}\text { Credit* } \\
\text { incr HPI }\end{array}$ & interaction of the credit constraint and increasing HPI variables & \\
\hline $\begin{array}{l}\text { Credit* } \\
\text { non-incr HPI }\end{array}$ & interaction of the credit constraint and non-increasing HPI variables & \\
\hline
\end{tabular}


Table 2: Descriptive Statistics (Entire Population and Recent Movers)

\begin{tabular}{|c|c|c|c|c|c|}
\hline \multicolumn{2}{|l|}{ Variables } & \multicolumn{2}{|c|}{$\begin{array}{c}\text { Mean } \\
\text { (Entire Population) }\end{array}$} & \multicolumn{2}{|c|}{$\begin{array}{c}\text { Mean } \\
\text { (Recent Movers) }\end{array}$} \\
\hline & & \multicolumn{2}{|l|}{2003} & \multirow{2}{*}{$\frac{2003}{43.12}$} & 2007 \\
\hline \multirow[t]{3}{*}{ Respondent Age } & All & 43.34 & 46.82 & & 46.66 \\
\hline & Owners & 43.41 & 46.86 & 43.20 & 46.61 \\
\hline & Renters & 43.15 & 46.72 & 43.06 & 46.69 \\
\hline \multirow[t]{3}{*}{ Black (\%) } & All & 13.36 & 13.30 & 17.38 & 20.70 \\
\hline & Owners & 8.85 & 8.55 & 9.57 & 10.46 \\
\hline & Renters & 24.70 & 26.04 & 24.28 & 27.16 \\
\hline \multirow[t]{3}{*}{ Hispanic (\%) } & All & 6.46 & 6.26 & 7.47 & 7.55 \\
\hline & Owners & 5.51 & 5.23 & 6.78 & 5.73 \\
\hline & Renters & 8.84 & 9.00 & 8.08 & 8.70 \\
\hline \multirow{3}{*}{ In MSA (\%) } & All & 79.03 & 91.71 & 81.00 & 94.15 \\
\hline & Owners & 78.20 & 91.07 & 79.22 & 92.11 \\
\hline & Renters & 81.11 & 93.43 & 82.57 & 95.43 \\
\hline \multirow[t]{3}{*}{ Highest Grade } & All & 13.57 & 13.71 & 13.26 & 13.19 \\
\hline & Owners & 13.93 & 14.03 & 13.96 & 13.83 \\
\hline & Renters & 12.68 & 12.85 & 12.64 & 12.78 \\
\hline \multirow[t]{3}{*}{ Married (\%) } & All & 63.30 & 61.53 & 45.46 & 37.86 \\
\hline & Owners & 77.53 & 74.86 & 68.34 & 60.66 \\
\hline & Renters & 27.52 & 25.82 & 25.26 & 23.46 \\
\hline \multirow[t]{3}{*}{ Kids (\%) } & All & 64.67 & 57.69 & 52.53 & 43.33 \\
\hline & Owners & 73.23 & 65.10 & 63.60 & 53.02 \\
\hline & Renters & 43.15 & 37.87 & 42.76 & 37.22 \\
\hline \multirow[t]{3}{*}{ Family Size } & All & 3.10 & 2.87 & 2.65 & 2.37 \\
\hline & Owners & 3.35 & 3.07 & 3.01 & 2.65 \\
\hline & Renters & 2.49 & 2.34 & 2.33 & 2.20 \\
\hline \multirow[t]{3}{*}{ Log Family Income } & All & 10.89 & 10.98 & 10.57 & 10.45 \\
\hline & Owners & 11.16 & 11.25 & 11.14 & 11.00 \\
\hline & Renters & 10.14 & 10.19 & 10.04 & 10.08 \\
\hline \multirow[t]{3}{*}{ Wealth } & All & 251,822 & 350,557 & 175,342 & 167,299 \\
\hline & Owners & 338,303 & 462,566 & 337,632 & 352,292 \\
\hline & Renters & 34,402 & 50,477 & 32,122 & 50,535 \\
\hline Home Value & Owners & 231,072 & 280,530 & 264,737 & 265,351 \\
\hline Home Owner (\%) & All & 71.54 & 72.82 & 46.88 & 38.69 \\
\hline \multirow[t]{3}{*}{ Credit Constraint (\%) } & All & 20.91 & 20.90 & 27.93 & 30.29 \\
\hline & Owners & 16.40 & 16.18 & 20.09 & 23.40 \\
\hline & Renters & 32.26 & 33.52 & 34.85 & 34.64 \\
\hline \multirow[t]{3}{*}{ Observation } & All & 7,132 & 7,084 & 1,962 & 1,591 \\
\hline & Owners & 4,567 & 4,597 & 778 & 508 \\
\hline & Renters & 2,565 & 2,487 & 1,184 & 1,083 \\
\hline
\end{tabular}


Table 3: Two-Stage Housing Demand

\begin{tabular}{|c|c|c|c|c|}
\hline \multirow{2}{*}{ VARIABLES } & \multicolumn{2}{|c|}{2003} & \multicolumn{2}{|c|}{2007} \\
\hline & Home Value & Constrained & Home Value & Constrained \\
\hline Log Income & $\begin{array}{c}0.45^{* * *} \\
(0.03)\end{array}$ & $\begin{array}{c}0.65^{* * *} \\
(0.03)\end{array}$ & $\begin{array}{c}0.49^{* * *} \\
(0.04)\end{array}$ & $\begin{array}{c}0.58^{* * *} \\
(0.04)\end{array}$ \\
\hline Married & $\begin{array}{c}-0.41^{* * *} \\
(0.05)\end{array}$ & $\begin{array}{c}0.49^{* * *} \\
(0.07)\end{array}$ & $\begin{array}{c}-0.57^{* * *} \\
(0.05)\end{array}$ & $\begin{array}{c}0.58^{* * * *} \\
(0.07)\end{array}$ \\
\hline Log Family size & $\begin{array}{c}0.14^{* * *} \\
(0.04)\end{array}$ & $\begin{array}{c}-0.08 \\
(0.05)\end{array}$ & $\begin{array}{c}0.19^{* * *} \\
(0.04)\end{array}$ & $\begin{array}{c}-0.19^{* * *} \\
(0.05)\end{array}$ \\
\hline East North Central Region & $\begin{array}{l}-0.12 \\
(0.10)\end{array}$ & $\begin{array}{c}0.07 \\
(0.14)\end{array}$ & $\begin{array}{l}-0.07 \\
(0.07)\end{array}$ & $\begin{array}{c}0.11 \\
(0.08)\end{array}$ \\
\hline Mid-Atlantic Region & $\begin{array}{l}-0.17^{*} \\
(0.10)\end{array}$ & $\begin{array}{c}0.16 \\
(0.13)\end{array}$ & $\begin{array}{l}-0.00 \\
(0.08)\end{array}$ & $\begin{array}{c}0.01 \\
(0.09)\end{array}$ \\
\hline Mountain Region & $\begin{array}{c}0.13 \\
(0.08)\end{array}$ & $\begin{array}{c}-0.19^{*} \\
(0.11)\end{array}$ & $\begin{array}{c}0.11 \\
(0.10)\end{array}$ & $\begin{array}{l}-0.08 \\
(0.11)\end{array}$ \\
\hline New England & $\begin{array}{c}0.08 \\
(0.12)\end{array}$ & $\begin{array}{c}0.02 \\
(0.17)\end{array}$ & $\begin{array}{c}0.38^{* * *} \\
(0.10)\end{array}$ & $\begin{array}{c}-0.43^{* * *} \\
(0.11)\end{array}$ \\
\hline Pacific Region & $\begin{array}{c}0.34^{* *} \\
(0.14)\end{array}$ & $\begin{array}{l}-0.32^{*} \\
(0.18)\end{array}$ & $\begin{array}{c}0.24 \\
(0.16)\end{array}$ & $\begin{array}{l}-0.25 \\
(0.18)\end{array}$ \\
\hline South Atlantic Region & $\begin{array}{l}-0.05 \\
(0.11)\end{array}$ & $\begin{array}{l}-0.06 \\
(0.14)\end{array}$ & $\begin{array}{c}0.03 \\
(0.07)\end{array}$ & $\begin{array}{l}-0.01 \\
(0.08)\end{array}$ \\
\hline West North Central Region & $\begin{array}{l}-0.14 \\
(0.11)\end{array}$ & $\begin{array}{l}0.26^{*} \\
(0.15)\end{array}$ & $\begin{array}{l}-0.05 \\
(0.08)\end{array}$ & $\begin{array}{c}0.05 \\
(0.10)\end{array}$ \\
\hline West South Central Region & $\begin{array}{c}-0.29 * * * \\
(0.11)\end{array}$ & $\begin{array}{c}0.01 \\
(0.15)\end{array}$ & $\begin{array}{c}-0.19^{* *} \\
(0.10)\end{array}$ & $\begin{array}{c}0.14 \\
(0.14)\end{array}$ \\
\hline East South Central Region & $\begin{array}{c}-0.39^{* * *} \\
(0.11)\end{array}$ & $\begin{array}{c}0.26 \\
(0.16)\end{array}$ & $\begin{array}{l}-0.18^{*} \\
(0.10)\end{array}$ & $\begin{array}{c}0.15 \\
(0.11)\end{array}$ \\
\hline California or Hawaii & $\begin{array}{c}0.48^{* * *} \\
(0.12)\end{array}$ & $\begin{array}{c}-0.58^{* * *} \\
(0.14)\end{array}$ & $\begin{array}{c}0.63^{* * *} \\
(0.09)\end{array}$ & $\begin{array}{c}-0.68^{* * *} \\
(0.11)\end{array}$ \\
\hline Boston MSA & $\begin{array}{c}0.47^{* * *} \\
(0.15)\end{array}$ & $\begin{array}{c}-0.55^{* *} \\
(0.22)\end{array}$ & $\begin{array}{c}0.29 \\
(0.19)\end{array}$ & $\begin{array}{c}-0.28 \\
(0.23)\end{array}$ \\
\hline NY MSA & $\begin{array}{c}0.74^{* * *} \\
(0.08)\end{array}$ & $\begin{array}{c}-0.79^{* * *} \\
(0.11)\end{array}$ & $\begin{array}{c}0.77^{* * *} \\
(0.08)\end{array}$ & $\begin{array}{c}-0.80^{* * *} \\
(0.09)\end{array}$ \\
\hline DC MSA & $\begin{array}{c}0.46^{* * *} \\
(0.10)\end{array}$ & $\begin{array}{c}-0.51^{* * *} \\
(0.14)\end{array}$ & $\begin{array}{c}0.47^{* * *} \\
(0.09)\end{array}$ & $\begin{array}{c}-0.48^{* * *} \\
(0.12)\end{array}$ \\
\hline In MSA & $\begin{array}{c}0.42^{* * * *} \\
(0.04)\end{array}$ & $\begin{array}{c}-0.43^{* * *} * \\
(0.05)\end{array}$ & $\begin{array}{c}0.33^{* * * *} \\
(0.06)\end{array}$ & $\begin{array}{c}-0.32^{* * * *} \\
(0.07)\end{array}$ \\
\hline Constant & $\begin{array}{c}7.19^{* * * *} \\
(0.34) \\
\end{array}$ & $\begin{array}{c}-6.88^{* * *} \\
(0.38) \\
\end{array}$ & $\begin{array}{c}6.87 * * * \\
(0.53)\end{array}$ & $\begin{array}{c}-6.22^{* * *} \\
(0.42)\end{array}$ \\
\hline Rho & $\begin{array}{c}-2.37 * * * \\
(0.18)\end{array}$ & & $\begin{array}{c}-3.57 * * * \\
(1.23)\end{array}$ & \\
\hline Sigma & $\begin{array}{c}-0.26 * * * \\
(0.04) \\
\end{array}$ & & $\begin{array}{l}-0.11^{*} \\
(0.06) \\
\end{array}$ & \\
\hline Observations & 6,130 & 6,130 & 6,084 & 6,084 \\
\hline
\end{tabular}

Robust standard errors in parentheses ${ }^{* * *} \mathrm{p}<0.01,{ }^{* *} \mathrm{p}<0.05,{ }^{*} \mathrm{p}<0.1$ 


\section{Table 4: Recent Movers and Financing Constraints}

\begin{tabular}{|c|c|c|c|c|c|c|}
\hline \multirow{2}{*}{$\begin{array}{l}\text { Constraint } \\
\text { Not Wealth } \\
\text { Wealth }\end{array}$} & \multicolumn{2}{|c|}{$\begin{array}{c}20032007 \\
\text { All } \\
(\%)\end{array}$} & $\begin{array}{r}2 \\
\text { Renter } \\
(\%)\end{array}$ & $\begin{array}{l}3 \\
\text { Owner } \\
(\%)\end{array}$ & $\begin{array}{r}2 \\
\text { Renter } \\
(\%)\end{array}$ & $\begin{array}{l}7 \\
\text { Owner } \\
(\%)\end{array}$ \\
\hline & $\begin{array}{l}56 \\
44\end{array}$ & $\begin{array}{l}48 \\
52\end{array}$ & $\begin{array}{l}31 \\
69\end{array}$ & $\begin{array}{l}83 \\
17\end{array}$ & $\begin{array}{l}29 \\
71\end{array}$ & $\begin{array}{l}77 \\
23\end{array}$ \\
\hline $\begin{array}{l}\text { Not Income } \\
\text { Income }\end{array}$ & $\begin{array}{l}30 \\
70\end{array}$ & $\begin{array}{l}19 \\
81\end{array}$ & $\begin{array}{l}11 \\
89\end{array}$ & $\begin{array}{l}51 \\
49\end{array}$ & $\begin{array}{c}9 \\
91\end{array}$ & $\begin{array}{l}34 \\
66\end{array}$ \\
\hline $\begin{array}{l}\text { Not Credit } \\
\text { Credit }\end{array}$ & $\begin{array}{l}72 \\
28\end{array}$ & $\begin{array}{l}70 \\
30\end{array}$ & $\begin{array}{l}65 \\
35\end{array}$ & $\begin{array}{l}80 \\
20\end{array}$ & $\begin{array}{l}65 \\
35\end{array}$ & $\begin{array}{l}77 \\
23\end{array}$ \\
\hline $\begin{array}{l}\text { Wealth and Credit } \\
\text { All constraints } \\
\text { No constraints }\end{array}$ & $\begin{array}{l}15 \\
14 \\
22\end{array}$ & $\begin{array}{l}18 \\
17 \\
14\end{array}$ & $\begin{array}{c}24 \\
23 \\
5\end{array}$ & $\begin{array}{c}5 \\
4 \\
42\end{array}$ & $\begin{array}{c}25 \\
23 \\
5\end{array}$ & $\begin{array}{c}7 \\
6 \\
28\end{array}$ \\
\hline Total & & & 53 & 47 & 61 & 39 \\
\hline
\end{tabular}

The computations in the table use sample weights. 
Table 5: Probability of Homeownership - Model A Recent Movers

\begin{tabular}{|c|c|c|c|c|c|c|c|c|}
\hline \multirow[t]{2}{*}{ MODELS } & \multicolumn{2}{|c|}{ Model A1 } & \multicolumn{2}{|c|}{ Model A2 } & \multicolumn{2}{|c|}{ Model A3 } & \multicolumn{2}{|c|}{ Model A4 } \\
\hline & 2003 & 2007 & 2003 & 2007 & 2003 & 2007 & 2003 & 2007 \\
\hline Log Income & $\begin{array}{c}0.31^{* * *} \\
(0.06)\end{array}$ & $\begin{array}{c}0.16^{* *} \\
(0.07)\end{array}$ & $\begin{array}{c}0.34^{* * *} \\
(0.07)\end{array}$ & $\begin{array}{c}0.16^{* *} \\
(0.07)\end{array}$ & $\begin{array}{c}0.37^{* * *} \\
(0.07)\end{array}$ & $\begin{array}{c}0.21^{* * *} \\
(0.08)\end{array}$ & $\begin{array}{c}0.37^{* * *} \\
(0.07)\end{array}$ & $\begin{array}{c}0.21^{* * *} \\
(0.08)\end{array}$ \\
\hline Wealth Constraint & $\begin{array}{c}-1.44^{* * *} \\
(0.11)\end{array}$ & $\begin{array}{c}-1.25^{* * *} \\
(0.12)\end{array}$ & $\begin{array}{c}-1.44^{* * *} \\
(0.11)\end{array}$ & $\begin{array}{c}-1.25^{* * *} \\
(0.12)\end{array}$ & $\begin{array}{c}-1.45^{* * *} \\
(0.11)\end{array}$ & $\begin{array}{c}-1.25^{* * *} \\
(0.12)\end{array}$ & $\begin{array}{c}-1.45^{* * *} \\
(0.11)\end{array}$ & $\begin{array}{c}-1.25^{* * *} \\
(0.12)\end{array}$ \\
\hline Income Constraint & $\begin{array}{c}-0.45^{* * *} \\
(0.13)\end{array}$ & $\begin{array}{l}-0.00 \\
(0.16)\end{array}$ & $\begin{array}{c}-0.35^{* * *} \\
(0.13)\end{array}$ & $\begin{array}{c}0.00 \\
(0.16)\end{array}$ & $\begin{array}{c}-0.28^{* *} \\
(0.13)\end{array}$ & $\begin{array}{c}0.12 \\
(0.17)\end{array}$ & $\begin{array}{c}-0.27^{* *} \\
(0.13)\end{array}$ & $\begin{array}{c}0.12 \\
(0.17)\end{array}$ \\
\hline Credit Constraint & $\begin{array}{c}-0.37^{* * *} \\
(0.11)\end{array}$ & $\begin{array}{l}-0.15 \\
(0.11)\end{array}$ & $\begin{array}{c}-0.36^{* * *} \\
(0.11)\end{array}$ & $\begin{array}{l}-0.15 \\
(0.11)\end{array}$ & $\begin{array}{c}-0.36^{* * *} \\
(0.11)\end{array}$ & $\begin{array}{c}-0.17 \\
(0.11)\end{array}$ & $\begin{array}{c}-0.36^{* * *} \\
(0.11)\end{array}$ & $\begin{array}{c}-0.17 \\
(0.11)\end{array}$ \\
\hline Change HPI & & & $\begin{array}{c}-1.03^{* *} \\
(0.45)\end{array}$ & $\begin{array}{l}-0.18 \\
(0.38)\end{array}$ & & & $\begin{array}{l}-0.25 \\
(0.56)\end{array}$ & $\begin{array}{c}0.24 \\
(0.40)\end{array}$ \\
\hline Value to Rent & & & & & $\begin{array}{c}-2.51^{* * *} \\
(0.66)\end{array}$ & $\begin{array}{c}-2.63^{* * *} \\
(0.62)\end{array}$ & $\begin{array}{c}-2.31^{* * *} \\
(0.82)\end{array}$ & $\begin{array}{c}-2.75^{* * *} \\
(0.64)\end{array}$ \\
\hline Married & $\begin{array}{c}0.26^{* *} \\
(0.12)\end{array}$ & $\begin{array}{c}0.49^{* * *} \\
(0.14)\end{array}$ & $\begin{array}{c}0.30^{* * *} \\
(0.12)\end{array}$ & $\begin{array}{c}0.50^{* * * *} \\
(0.14)\end{array}$ & $\begin{array}{c}0.31^{* * *} \\
(0.12)\end{array}$ & $\begin{array}{c}0.54^{* * *} \\
(0.14)\end{array}$ & $\begin{array}{c}0.32^{* * *} \\
(0.12)\end{array}$ & $\begin{array}{c}0.54^{* * *} \\
(0.14)\end{array}$ \\
\hline Black & $\begin{array}{c}-0.29^{* * *} \\
(0.10)\end{array}$ & $\begin{array}{c}-0.50^{* * *} \\
(0.10)\end{array}$ & $\begin{array}{c}-0.30^{* * *} \\
(0.10)\end{array}$ & $\begin{array}{c}-0.50^{* * *} \\
(0.10)\end{array}$ & $\begin{array}{c}-0.34^{* * *} \\
(0.10)\end{array}$ & $\begin{array}{c}-0.53^{* * *} \\
(0.11)\end{array}$ & $\begin{array}{c}-0.34^{* * *} \\
(0.10)\end{array}$ & $\begin{array}{c}-0.53^{* * *} \\
(0.11)\end{array}$ \\
\hline Hispanic & $\begin{array}{c}0.04 \\
(0.12)\end{array}$ & $\begin{array}{l}-0.22^{*} \\
(0.12)\end{array}$ & $\begin{array}{c}0.08 \\
(0.13)\end{array}$ & $\begin{array}{c}-0.21^{*} \\
(0.13)\end{array}$ & $\begin{array}{c}0.06 \\
(0.13)\end{array}$ & $\begin{array}{l}-0.15 \\
(0.13)\end{array}$ & $\begin{array}{c}0.07 \\
(0.13)\end{array}$ & $\begin{array}{c}-0.17 \\
(0.13)\end{array}$ \\
\hline Log Grade Attained & $\begin{array}{l}-0.31 \\
(0.24)\end{array}$ & $\begin{array}{c}0.09 \\
(0.28)\end{array}$ & $\begin{array}{l}-0.28 \\
(0.24)\end{array}$ & $\begin{array}{c}0.10 \\
(0.28)\end{array}$ & $\begin{array}{l}-0.24 \\
(0.25)\end{array}$ & $\begin{array}{c}0.16 \\
(0.28)\end{array}$ & $\begin{array}{l}-0.23 \\
(0.25)\end{array}$ & $\begin{array}{c}0.16 \\
(0.28)\end{array}$ \\
\hline Kids & $\begin{array}{c}0.37^{* * *} \\
(0.10)\end{array}$ & $\begin{array}{c}0.12 \\
(0.11) \\
\end{array}$ & $\begin{array}{c}0.37^{* * *} \\
(0.10)\end{array}$ & $\begin{array}{c}0.12 \\
(0.11)\end{array}$ & $\begin{array}{c}0.37^{* * *} \\
(0.10)\end{array}$ & $\begin{array}{c}0.10 \\
(0.11)\end{array}$ & $\begin{array}{c}0.37^{* * *} \\
(0.10)\end{array}$ & $\begin{array}{c}0.10 \\
(0.11)\end{array}$ \\
\hline Observations & 1658 & 1325 & 1658 & 1323 & 1658 & 1323 & 1658 & 1323 \\
\hline
\end{tabular}

Marginal effects; Standard errors in parentheses

${ }^{*} p<0.10,{ }^{* *} p<0.05,{ }^{* * *} p<0.01$ 
Table 6: Probability of Homeownership - Model A Recent Movers - Marginal effects

\begin{tabular}{|c|c|c|c|c|c|c|c|c|}
\hline \multirow[t]{2}{*}{ MODELS } & \multicolumn{2}{|c|}{ Model A1 } & \multicolumn{2}{|c|}{ Model A2 } & \multicolumn{2}{|c|}{ Model A3 } & \multicolumn{2}{|c|}{ Model A4 } \\
\hline & 2003 & 2007 & 2003 & 2007 & 2003 & 2007 & 2003 & 2007 \\
\hline Log Income & $\begin{array}{c}0.07^{* * *} \\
(0.01)\end{array}$ & $\begin{array}{c}0.04^{* *} \\
(0.02)\end{array}$ & $\begin{array}{c}0.08^{* * *} \\
(0.01)\end{array}$ & $\begin{array}{c}0.04^{* *} \\
(0.02)\end{array}$ & $\begin{array}{c}0.09^{* * *} \\
(0.02)\end{array}$ & $\begin{array}{c}0.05^{* * *} \\
(0.02)\end{array}$ & $\begin{array}{c}0.09^{* * *} \\
(0.02)\end{array}$ & $\begin{array}{c}0.05^{* * *} \\
(0.02)\end{array}$ \\
\hline Wealth Constraint & $\begin{array}{c}-0.43^{* * *} \\
(0.03)\end{array}$ & $\begin{array}{c}-0.39^{* * *} \\
(0.04)\end{array}$ & $\begin{array}{c}-0.43^{* * *} \\
(0.03)\end{array}$ & $\begin{array}{c}-0.39^{* * *} \\
(0.04)\end{array}$ & $\begin{array}{c}-0.42^{* * *} \\
(0.03)\end{array}$ & $\begin{array}{c}-0.38^{* * *} \\
(0.04)\end{array}$ & $\begin{array}{c}-0.42^{* * *} \\
(0.03)\end{array}$ & $\begin{array}{c}-0.38^{* * *} \\
(0.04)\end{array}$ \\
\hline Income Constraint & $\begin{array}{c}-0.12^{* * *} \\
(0.03)\end{array}$ & $\begin{array}{c}-0.00 \\
(0.04)\end{array}$ & $\begin{array}{c}-0.09^{* *} \\
(0.04)\end{array}$ & $\begin{array}{c}0.00 \\
(0.04)\end{array}$ & $\begin{array}{c}-0.07^{* *} \\
(0.03)\end{array}$ & $\begin{array}{c}0.03 \\
(0.04)\end{array}$ & $\begin{array}{l}-0.06^{*} \\
(0.03)\end{array}$ & $\begin{array}{c}0.03 \\
(0.04)\end{array}$ \\
\hline Credit Constraint & $\begin{array}{c}-0.09^{* * *} \\
(0.03)\end{array}$ & $\begin{array}{l}-0.04 \\
(0.03)\end{array}$ & $\begin{array}{c}-0.09^{* * *} \\
(0.03)\end{array}$ & $\begin{array}{c}-0.04 \\
(0.03)\end{array}$ & $\begin{array}{c}-0.09^{* * *} \\
(0.03)\end{array}$ & $\begin{array}{l}-0.05 \\
(0.03)\end{array}$ & $\begin{array}{c}-0.09^{* * *} \\
(0.03)\end{array}$ & $\begin{array}{l}-0.05 \\
(0.03)\end{array}$ \\
\hline Change HPI & & & $\begin{array}{c}-0.24^{* *} \\
(0.10)\end{array}$ & $\begin{array}{l}-0.05 \\
(0.10)\end{array}$ & & & $\begin{array}{c}-0.06 \\
(0.13)\end{array}$ & $\begin{array}{c}0.06 \\
(0.10)\end{array}$ \\
\hline Value to Rent & & & & & $\begin{array}{c}-0.58^{* * *} \\
(0.15)\end{array}$ & $\begin{array}{c}-0.69^{* * *} \\
(0.16)\end{array}$ & $\begin{array}{c}-0.54^{* * *} \\
(0.19)\end{array}$ & $\begin{array}{c}-0.72^{* * *} \\
(0.17)\end{array}$ \\
\hline Married & $\begin{array}{c}0.06^{* *} \\
(0.03)\end{array}$ & $\begin{array}{c}0.14^{* * *} \\
(0.04)\end{array}$ & $\begin{array}{c}0.07^{* *} \\
(0.03)\end{array}$ & $\begin{array}{c}0.14^{* * *} \\
(0.04)\end{array}$ & $\begin{array}{c}0.08^{* * *} \\
(0.03)\end{array}$ & $\begin{array}{c}0.15^{* * *} \\
(0.04)\end{array}$ & $\begin{array}{c}0.08^{* * *} \\
(0.03)\end{array}$ & $\begin{array}{c}0.15^{* * *} \\
(0.04)\end{array}$ \\
\hline Black & $\begin{array}{c}-0.07^{* * *} \\
(0.02)\end{array}$ & $\begin{array}{c}-0.13^{* * *} \\
(0.03)\end{array}$ & $\begin{array}{c}-0.07^{* * *} \\
(0.02)\end{array}$ & $\begin{array}{c}-0.13^{* * *} \\
(0.03)\end{array}$ & $\begin{array}{c}-0.08^{* * *} \\
(0.02)\end{array}$ & $\begin{array}{c}-0.14^{* * *} \\
(0.03)\end{array}$ & $\begin{array}{c}-0.08^{* * *} \\
(0.02)\end{array}$ & $\begin{array}{c}-0.14^{* * *} \\
(0.03)\end{array}$ \\
\hline Hispanic & $\begin{array}{c}0.01 \\
(0.03)\end{array}$ & $\begin{array}{c}-0.06^{*} \\
(0.03)\end{array}$ & $\begin{array}{c}0.02 \\
(0.03)\end{array}$ & $\begin{array}{c}-0.06^{*} \\
(0.03)\end{array}$ & $\begin{array}{c}0.01 \\
(0.03)\end{array}$ & $\begin{array}{c}-0.04 \\
(0.03)\end{array}$ & $\begin{array}{c}0.02 \\
(0.03)\end{array}$ & $\begin{array}{c}-0.04 \\
(0.03)\end{array}$ \\
\hline Log Grade Attained & $\begin{array}{l}-0.07 \\
(0.06)\end{array}$ & $\begin{array}{c}0.02 \\
(0.08)\end{array}$ & $\begin{array}{l}-0.07 \\
(0.06)\end{array}$ & $\begin{array}{c}0.03 \\
(0.08)\end{array}$ & $\begin{array}{l}-0.05 \\
(0.06)\end{array}$ & $\begin{array}{c}0.04 \\
(0.07)\end{array}$ & $\begin{array}{l}-0.05 \\
(0.06)\end{array}$ & $\begin{array}{c}0.04 \\
(0.07)\end{array}$ \\
\hline Kids & $\begin{array}{c}0.09^{* * *} \\
(0.02)\end{array}$ & $\begin{array}{c}0.03 \\
(0.03)\end{array}$ & $\begin{array}{c}0.09^{* * *} \\
(0.02)\end{array}$ & $\begin{array}{c}0.03 \\
(0.03)\end{array}$ & $\begin{array}{c}0.09^{* * *} \\
(0.02)\end{array}$ & $\begin{array}{c}0.03 \\
(0.03)\end{array}$ & $\begin{array}{c}0.09^{* * *} \\
(0.02)\end{array}$ & $\begin{array}{c}0.03 \\
(0.03)\end{array}$ \\
\hline Observations & 1658 & 1325 & 1658 & 1323 & 1658 & 1323 & 1658 & 1323 \\
\hline
\end{tabular}

Marginal effects; Standard errors in parentheses

${ }^{*} p<0.10,{ }^{* *} p<0.05,{ }^{* * *} p<0.01$ 
Table 7: Probability of Homeownership - Varying Debt to Income and Down Payment Recent Movers

\begin{tabular}{|c|c|c|c|c|c|c|}
\hline \multirow{2}{*}{ MODELS } & \multicolumn{2}{|c|}{ Down: 5 DTI: 28} & \multicolumn{2}{|c|}{ Down: 5 DTI: 30} & \multicolumn{2}{|c|}{ Down: 10 DTI: 28} \\
\hline & 2003 & 2007 & 2003 & 2007 & 2003 & 2007 \\
\hline Log Income & $\begin{array}{c}0.35^{* * *} \\
(0.07)\end{array}$ & $\begin{array}{c}0.17^{* * *} \\
(0.06)\end{array}$ & $\begin{array}{c}0.35^{* * * *} \\
(0.07)\end{array}$ & $\begin{array}{c}0.16^{* *} \\
(0.06)\end{array}$ & $\begin{array}{c}0.35^{* * *} \\
(0.06)\end{array}$ & $\begin{array}{c}0.21^{* * *} \\
(0.06)\end{array}$ \\
\hline Wealth Constraint & $\begin{array}{c}-1.51^{* * *} \\
(0.11)\end{array}$ & $\begin{array}{c}-1.38^{* * *} \\
(0.12)\end{array}$ & $\begin{array}{c}-1.50^{* * *} \\
(0.11)\end{array}$ & $\begin{array}{c}-1.41^{* * *} \\
(0.12)\end{array}$ & $\begin{array}{c}-1.48^{* * *} \\
(0.10)\end{array}$ & $\begin{array}{c}-1.31^{* * *} \\
(0.12)\end{array}$ \\
\hline Income Constraint & $\begin{array}{c}-0.31^{* *} \\
(0.15)\end{array}$ & $\begin{array}{c}0.02 \\
(0.21)\end{array}$ & $\begin{array}{c}-0.31^{* *} \\
(0.14)\end{array}$ & $\begin{array}{l}-0.08 \\
(0.21)\end{array}$ & $\begin{array}{c}-0.30^{* *} \\
(0.15)\end{array}$ & $\begin{array}{c}0.19 \\
(0.21)\end{array}$ \\
\hline Credit Constraint & $\begin{array}{c}-0.35^{* * *} \\
(0.11)\end{array}$ & $\begin{array}{l}-0.13 \\
(0.12)\end{array}$ & $\begin{array}{c}-0.35^{* * *} \\
(0.11)\end{array}$ & $\begin{array}{l}-0.12 \\
(0.12)\end{array}$ & $\begin{array}{c}-0.26^{* *} \\
(0.11)\end{array}$ & $\begin{array}{l}-0.12 \\
(0.11)\end{array}$ \\
\hline Value to Rent & $\begin{array}{c}-2.46^{* * *} \\
(0.65)\end{array}$ & $\begin{array}{c}-2.26^{* * *} \\
(0.61)\end{array}$ & $\begin{array}{c}-2.46^{* * *} \\
(0.65)\end{array}$ & $\begin{array}{c}-2.29^{* * *} \\
(0.60)\end{array}$ & $\begin{array}{c}-2.38^{* * *} \\
(0.67)\end{array}$ & $\begin{array}{c}-2.24^{* * *} \\
(0.59)\end{array}$ \\
\hline Married & $\begin{array}{c}0.31^{* * *} \\
(0.11)\end{array}$ & $\begin{array}{c}0.36^{* * *} \\
(0.13)\end{array}$ & $\begin{array}{c}0.30^{* * *} \\
(0.11)\end{array}$ & $\begin{array}{c}0.35^{* * *} \\
(0.13)\end{array}$ & $\begin{array}{l}0.29^{* *} \\
(0.11)\end{array}$ & $\begin{array}{c}0.34^{* *} \\
(0.13)\end{array}$ \\
\hline Black & $\begin{array}{c}-0.32^{* * *} \\
(0.10)\end{array}$ & $\begin{array}{c}-0.53^{* * *} \\
(0.11)\end{array}$ & $\begin{array}{c}-0.32^{* * *} \\
(0.10)\end{array}$ & $\begin{array}{c}-0.53^{* * *} \\
(0.11)\end{array}$ & $\begin{array}{c}-0.31^{* * *} \\
(0.10)\end{array}$ & $\begin{array}{c}-0.50^{* * *} \\
(0.10)\end{array}$ \\
\hline Hispanic & $\begin{array}{c}0.10 \\
(0.13)\end{array}$ & $\begin{array}{l}-0.11 \\
(0.12)\end{array}$ & $\begin{array}{c}0.11 \\
(0.13)\end{array}$ & $\begin{array}{l}-0.10 \\
(0.12)\end{array}$ & $\begin{array}{c}0.19 \\
(0.13)\end{array}$ & $\begin{array}{l}-0.18 \\
(0.12)\end{array}$ \\
\hline Log Grade Attained & $\begin{array}{l}-0.27 \\
(0.24)\end{array}$ & $\begin{array}{c}0.06 \\
(0.29)\end{array}$ & $\begin{array}{l}-0.26 \\
(0.24)\end{array}$ & $\begin{array}{c}0.01 \\
(0.28)\end{array}$ & $\begin{array}{l}-0.22 \\
(0.23)\end{array}$ & $\begin{array}{c}0.08 \\
(0.28)\end{array}$ \\
\hline Kids & $\begin{array}{c}0.36^{* * * *} \\
(0.10)\end{array}$ & $\begin{array}{c}0.12 \\
(0.11)\end{array}$ & $\begin{array}{c}0.36^{* * *} \\
(0.10)\end{array}$ & $\begin{array}{c}0.12 \\
(0.11)\end{array}$ & $\begin{array}{c}0.33^{* * *} \\
(0.10)\end{array}$ & $\begin{array}{l}0.18^{*} \\
(0.11)\end{array}$ \\
\hline Observations & 1658 & 1323 & 1658 & 1323 & 1658 & 1323 \\
\hline
\end{tabular}

Standard errors in parentheses

${ }^{*} p<0.10,{ }^{* *} p<0.05,{ }^{* * *} p<0.01$ 
Table 8: Probability of Homeownership - Constraints Combined Recent Movers

\begin{tabular}{|c|c|c|c|c|c|c|}
\hline \multirow[t]{2}{*}{ MODELS } & \multicolumn{2}{|c|}{ A1 } & \multicolumn{2}{|c|}{$\mathrm{A} 2$} & \multicolumn{2}{|c|}{ A3 } \\
\hline & 2003 & 2007 & 2003 & 2007 & 2003 & 2007 \\
\hline Log Income & $\begin{array}{c}0.48^{* * *} \\
(0.07)\end{array}$ & $\begin{array}{c}0.27^{* * *} \\
(0.08)\end{array}$ & $\begin{array}{c}0.50^{* * *} \\
(0.07)\end{array}$ & $\begin{array}{c}0.28^{* * *} \\
(0.08)\end{array}$ & $\begin{array}{c}0.53^{* * *} \\
(0.07)\end{array}$ & $\begin{array}{c}0.31^{* * *} \\
(0.09)\end{array}$ \\
\hline Constrained & $\begin{array}{c}-0.88^{* * *} \\
(0.16)\end{array}$ & $\begin{array}{c}-0.50^{* *} \\
(0.24)\end{array}$ & $\begin{array}{c}-0.79^{* * *} \\
(0.16)\end{array}$ & $\begin{array}{c}-0.49^{* *} \\
(0.24)\end{array}$ & $\begin{array}{c}-0.74^{* * *} \\
(0.16)\end{array}$ & $\begin{array}{l}-0.48^{*} \\
(0.25)\end{array}$ \\
\hline Change HPI & & & $\begin{array}{c}-1.19^{* * *} \\
(0.40)\end{array}$ & $\begin{array}{l}-0.27 \\
(0.36)\end{array}$ & & \\
\hline Value to Rent & & & & & $\begin{array}{c}-2.63^{* * *} \\
(0.60)\end{array}$ & $\begin{array}{c}-2.59^{* * *} \\
(0.57)\end{array}$ \\
\hline Married & $\begin{array}{c}0.36^{* * *} \\
(0.11)\end{array}$ & $\begin{array}{c}0.51^{* * *} \\
(0.12)\end{array}$ & $\begin{array}{c}0.38^{* * *} \\
(0.11)\end{array}$ & $\begin{array}{c}0.52^{* * *} \\
(0.12)\end{array}$ & $\begin{array}{c}0.37^{* * *} \\
(0.11)\end{array}$ & $\begin{array}{c}0.51^{* * *} \\
(0.12)\end{array}$ \\
\hline Black & $\begin{array}{c}-0.39^{* * *} \\
(0.09)\end{array}$ & $\begin{array}{c}-0.58^{* * *} \\
(0.10)\end{array}$ & $\begin{array}{c}-0.40^{* * *} \\
(0.09)\end{array}$ & $\begin{array}{c}-0.58^{* * *} \\
(0.10)\end{array}$ & $\begin{array}{c}-0.43^{* * *} \\
(0.09)\end{array}$ & $\begin{array}{c}-0.61^{* * *} \\
(0.10)\end{array}$ \\
\hline Hispanic & $\begin{array}{c}0.01 \\
(0.11)\end{array}$ & $\begin{array}{c}-0.24^{* *} \\
(0.12)\end{array}$ & $\begin{array}{c}0.07 \\
(0.12)\end{array}$ & $\begin{array}{l}-0.23^{*} \\
(0.12)\end{array}$ & $\begin{array}{c}0.05 \\
(0.11)\end{array}$ & $\begin{array}{l}-0.18 \\
(0.12)\end{array}$ \\
\hline Log Grade Attained & $\begin{array}{c}0.08 \\
(0.22)\end{array}$ & $\begin{array}{c}0.52^{*} \\
(0.28)\end{array}$ & $\begin{array}{c}0.12 \\
(0.23)\end{array}$ & $\begin{array}{c}0.53^{*} \\
(0.28)\end{array}$ & $\begin{array}{c}0.17 \\
(0.23)\end{array}$ & $\begin{array}{c}0.58^{* *} \\
(0.28)\end{array}$ \\
\hline Kids & $\begin{array}{l}0.22^{* *} \\
(0.09)\end{array}$ & $\begin{array}{c}0.14 \\
(0.10)\end{array}$ & $\begin{array}{c}0.23^{* *} \\
(0.09)\end{array}$ & $\begin{array}{c}0.14 \\
(0.10)\end{array}$ & $\begin{array}{c}0.23^{* * *} \\
(0.09)\end{array}$ & $\begin{array}{c}0.13 \\
(0.10)\end{array}$ \\
\hline Observations & 1658 & 1325 & 1658 & 1323 & 1658 & 1323 \\
\hline
\end{tabular}

Standard errors in parentheses

${ }^{*} p<0.10,{ }^{* *} p<0.05,{ }^{* * *} p<0.01$ 
Table 9: Probability of Homeownership

Recent Movers with Previous Tenure

\begin{tabular}{|c|c|c|c|c|c|c|}
\hline \multirow{2}{*}{ MODELS } & \multicolumn{2}{|c|}{ All Movers } & \multicolumn{2}{|c|}{ Previously Owners } & \multicolumn{2}{|c|}{ Previously Renters } \\
\hline & 2003 & 2007 & 2003 & 2007 & 2003 & 2007 \\
\hline Log Income & $\begin{array}{c}0.37^{* * * *} \\
(0.07)\end{array}$ & $\begin{array}{c}0.21^{* * * *} \\
(0.08)\end{array}$ & $\begin{array}{c}0.23^{* *} \\
(0.10)\end{array}$ & $\begin{array}{l}0.21^{*} \\
(0.12)\end{array}$ & $\begin{array}{c}0.50^{* * *} \\
(0.11)\end{array}$ & $\begin{array}{c}0.18^{*} \\
(0.10)\end{array}$ \\
\hline Wealth Constraint & $\begin{array}{c}-1.45^{* * *} \\
(0.11)\end{array}$ & $\begin{array}{c}-1.25^{* * *} \\
(0.12)\end{array}$ & $\begin{array}{c}-1.30^{* * *} \\
(0.19)\end{array}$ & $\begin{array}{c}-1.31^{* * *} \\
(0.21)\end{array}$ & $\begin{array}{c}-1.39^{* * *} \\
(0.14)\end{array}$ & $\begin{array}{c}-1.10^{* * *} \\
(0.15)\end{array}$ \\
\hline Income Constraint & $\begin{array}{c}-0.28^{* *} \\
(0.13)\end{array}$ & $\begin{array}{c}0.12 \\
(0.17)\end{array}$ & $\begin{array}{c}-0.38^{*} \\
(0.20)\end{array}$ & $\begin{array}{c}0.16 \\
(0.24)\end{array}$ & $\begin{array}{c}-0.14 \\
(0.19)\end{array}$ & $\begin{array}{c}0.12 \\
(0.24)\end{array}$ \\
\hline Credit Constraint & $\begin{array}{c}-0.36^{* * *} \\
(0.11)\end{array}$ & $\begin{array}{l}-0.17 \\
(0.11)\end{array}$ & $\begin{array}{c}-0.55^{* * *} \\
(0.15)\end{array}$ & $\begin{array}{l}-0.22 \\
(0.18)\end{array}$ & $\begin{array}{c}-0.31^{* *} \\
(0.15)\end{array}$ & $\begin{array}{l}-0.11 \\
(0.15)\end{array}$ \\
\hline Value to Rent & $\begin{array}{c}-2.51^{* * *} \\
(0.66)\end{array}$ & $\begin{array}{c}-2.63^{* * *} \\
(0.62)\end{array}$ & $\begin{array}{l}-1.49 \\
(1.06)\end{array}$ & $\begin{array}{l}-1.38 \\
(1.01)\end{array}$ & $\begin{array}{c}-3.39^{* * *} \\
(0.91)\end{array}$ & $\begin{array}{c}-3.15^{* * *} \\
(0.82)\end{array}$ \\
\hline Married & $\begin{array}{c}0.31^{* * *} \\
(0.12)\end{array}$ & $\begin{array}{c}0.54^{* * *} \\
(0.14)\end{array}$ & $\begin{array}{l}0.37^{* *} \\
(0.18)\end{array}$ & $\begin{array}{l}0.48^{* *} \\
(0.21)\end{array}$ & $\begin{array}{l}0.27^{*} \\
(0.16)\end{array}$ & $\begin{array}{c}0.62^{* * *} \\
(0.19)\end{array}$ \\
\hline Black & $\begin{array}{c}-0.34^{* * *} \\
(0.10)\end{array}$ & $\begin{array}{c}-0.53^{* * *} \\
(0.11)\end{array}$ & $\begin{array}{l}-0.24 \\
(0.17)\end{array}$ & $\begin{array}{c}-0.44^{* * *} \\
(0.16)\end{array}$ & $\begin{array}{c}-0.27^{* *} \\
(0.13)\end{array}$ & $\begin{array}{c}-0.51^{* * *} \\
(0.14)\end{array}$ \\
\hline Hispanic & $\begin{array}{c}0.06 \\
(0.13)\end{array}$ & $\begin{array}{l}-0.15 \\
(0.13)\end{array}$ & $\begin{array}{l}-0.08 \\
(0.19)\end{array}$ & $\begin{array}{l}-0.11 \\
(0.19)\end{array}$ & $\begin{array}{c}0.20 \\
(0.17)\end{array}$ & $\begin{array}{l}-0.13 \\
(0.18)\end{array}$ \\
\hline Log Grade Attained & $\begin{array}{c}-0.24 \\
(0.25)\end{array}$ & $\begin{array}{c}0.16 \\
(0.28)\end{array}$ & $\begin{array}{l}-0.68 \\
(0.43)\end{array}$ & $\begin{array}{l}-0.15 \\
(0.47)\end{array}$ & $\begin{array}{l}-0.17 \\
(0.33)\end{array}$ & $\begin{array}{c}0.29 \\
(0.38)\end{array}$ \\
\hline Kids & $\begin{array}{c}0.37^{* * * *} \\
(0.10)\end{array}$ & $\begin{array}{c}0.10 \\
(0.11) \\
\end{array}$ & $\begin{array}{c}0.52^{* * *} \\
(0.15)\end{array}$ & $\begin{array}{c}0.14 \\
(0.17) \\
\end{array}$ & $\begin{array}{c}0.16 \\
(0.14) \\
\end{array}$ & $\begin{array}{l}-0.05 \\
(0.15) \\
\end{array}$ \\
\hline Observations & 1658 & 1323 & 637 & 469 & 1021 & 854 \\
\hline
\end{tabular}

Standard errors in parentheses

${ }^{*} p<0.10,{ }^{* *} p<0.05,{ }^{* * *} p<0.01$ 
Table 10: Probability of Homeownership - Model B

Recent Movers

8oth Percentile of the HPI Distribution

\begin{tabular}{|c|c|c|c|c|c|c|}
\hline \multirow[t]{2}{*}{ MODELS } & \multicolumn{2}{|c|}{ Model B1 } & \multicolumn{2}{|c|}{ Model B2 } & \multicolumn{2}{|c|}{ Model B3 } \\
\hline & 2003 & 2007 & 2003 & 2007 & 2003 & 2007 \\
\hline Log Income & $\begin{array}{c}0.32^{* * *} \\
(0.06)\end{array}$ & $\begin{array}{l}0.16^{* *} \\
(0.07)\end{array}$ & $\begin{array}{c}0.34^{* * *} \\
(0.06)\end{array}$ & $\begin{array}{c}0.16^{* *} \\
(0.07)\end{array}$ & $\begin{array}{c}0.37^{* * *} \\
(0.07)\end{array}$ & $\begin{array}{c}0.21^{* * *} \\
(0.08)\end{array}$ \\
\hline Income Constr*incr HPI & $\begin{array}{c}-0.62^{* * *} \\
(0.16)\end{array}$ & $\begin{array}{l}-0.04 \\
(0.23)\end{array}$ & $\begin{array}{c}-0.26 \\
(0.21)\end{array}$ & $\begin{array}{c}0.00 \\
(0.25)\end{array}$ & $\begin{array}{c}-0.35^{* *} \\
(0.17)\end{array}$ & $\begin{array}{c}0.15 \\
(0.24)\end{array}$ \\
\hline Income Constr*non-incr HPI & $\begin{array}{c}-0.36^{* *} \\
(0.14)\end{array}$ & $\begin{array}{c}0.01 \\
(0.17)\end{array}$ & $\begin{array}{c}-0.36^{* *} \\
(0.14)\end{array}$ & $\begin{array}{c}0.00 \\
(0.17)\end{array}$ & $\begin{array}{c}-0.27^{*} \\
(0.14)\end{array}$ & $\begin{array}{c}0.11 \\
(0.17)\end{array}$ \\
\hline Wealth Constr*incr HPI & $\begin{array}{c}-1.59^{* * *} \\
(0.22)\end{array}$ & $\begin{array}{c}-1.20^{* * *} \\
(0.23)\end{array}$ & $\begin{array}{c}-1.58^{* * *} \\
(0.22)\end{array}$ & $\begin{array}{c}-1.19^{* * *} \\
(0.23)\end{array}$ & $\begin{array}{c}-1.59^{* * *} \\
(0.22)\end{array}$ & $\begin{array}{c}-1.20^{* * *} \\
(0.23)\end{array}$ \\
\hline Wealth Constr*non-incr HPI & $\begin{array}{c}-1.40^{* * *} \\
(0.12)\end{array}$ & $\begin{array}{c}-1.26^{* * *} \\
(0.13)\end{array}$ & $\begin{array}{c}-1.40^{* * *} \\
(0.13)\end{array}$ & $\begin{array}{c}-1.26^{* * *} \\
(0.13)\end{array}$ & $\begin{array}{c}-1.40^{* * *} \\
(0.13)\end{array}$ & $\begin{array}{c}-1.26^{* * *} \\
(0.13)\end{array}$ \\
\hline Credit Constr*incr HPI & $\begin{array}{c}-0.04 \\
(0.19)\end{array}$ & $\begin{array}{l}-0.16 \\
(0.24)\end{array}$ & $\begin{array}{c}0.01 \\
(0.19)\end{array}$ & $\begin{array}{l}-0.16 \\
(0.24)\end{array}$ & $\begin{array}{c}-0.04 \\
(0.19)\end{array}$ & $\begin{array}{l}-0.15 \\
(0.24)\end{array}$ \\
\hline Credit Constr*non-incr HPI & $\begin{array}{c}-0.48^{* * *} \\
(0.12)\end{array}$ & $\begin{array}{c}-0.14 \\
(0.13)\end{array}$ & $\begin{array}{c}-0.50^{* * *} \\
(0.13)\end{array}$ & $\begin{array}{l}-0.15 \\
(0.13)\end{array}$ & $\begin{array}{c}-0.47^{* * *} \\
(0.12)\end{array}$ & $\begin{array}{l}-0.18 \\
(0.13)\end{array}$ \\
\hline Change HPI & & & $\begin{array}{c}-1.78^{* *} \\
(0.77)\end{array}$ & $\begin{array}{l}-0.22 \\
(0.50)\end{array}$ & & \\
\hline Value to Rent & & & & & $\begin{array}{c}-2.53^{* * *} \\
(0.76)\end{array}$ & $\begin{array}{c}-2.70^{* * *} \\
(0.63)\end{array}$ \\
\hline Married & $\begin{array}{l}0.29^{* *} \\
(0.12)\end{array}$ & $\begin{array}{c}0.50^{* * *} \\
(0.14)\end{array}$ & $\begin{array}{c}0.32^{* * *} \\
(0.12)\end{array}$ & $\begin{array}{c}0.50^{* * *} \\
(0.14)\end{array}$ & $\begin{array}{c}0.33^{* * *} \\
(0.12)\end{array}$ & $\begin{array}{c}0.54^{* * *} \\
(0.14)\end{array}$ \\
\hline Black & $\begin{array}{c}-0.31^{* * *} \\
(0.10)\end{array}$ & $\begin{array}{c}-0.50^{* * *} \\
(0.10)\end{array}$ & $\begin{array}{c}-0.31^{* * *} \\
(0.10)\end{array}$ & $\begin{array}{c}-0.50^{* * *} \\
(0.10)\end{array}$ & $\begin{array}{c}-0.35^{* * *} \\
(0.10)\end{array}$ & $\begin{array}{c}-0.53^{* * *} \\
(0.11)\end{array}$ \\
\hline Hispanic & $\begin{array}{c}0.06 \\
(0.13)\end{array}$ & $\begin{array}{c}-0.21^{*} \\
(0.13)\end{array}$ & $\begin{array}{c}0.08 \\
(0.13)\end{array}$ & $\begin{array}{l}-0.21 \\
(0.13)\end{array}$ & $\begin{array}{c}0.06 \\
(0.13)\end{array}$ & $\begin{array}{l}-0.17 \\
(0.13)\end{array}$ \\
\hline Log Grade Attained & $\begin{array}{l}-0.30 \\
(0.24)\end{array}$ & $\begin{array}{c}0.09 \\
(0.28)\end{array}$ & $\begin{array}{l}-0.28 \\
(0.24)\end{array}$ & $\begin{array}{c}0.09 \\
(0.28)\end{array}$ & $\begin{array}{l}-0.24 \\
(0.24)\end{array}$ & $\begin{array}{c}0.16 \\
(0.28)\end{array}$ \\
\hline Kids & $\begin{array}{c}0.36^{* * *} \\
(0.10)\end{array}$ & $\begin{array}{c}0.12 \\
(0.11)\end{array}$ & $\begin{array}{c}0.37^{* * *} \\
(0.10)\end{array}$ & $\begin{array}{c}0.12 \\
(0.11)\end{array}$ & $\begin{array}{c}0.37^{* * *} \\
(0.10)\end{array}$ & $\begin{array}{c}0.11 \\
(0.11)\end{array}$ \\
\hline Constant & $\begin{array}{c}-2.11^{* *} \\
(0.82)\end{array}$ & $\begin{array}{l}-1.83^{*} \\
(0.95)\end{array}$ & $\begin{array}{c}-2.10^{* *} \\
(0.84)\end{array}$ & $\begin{array}{l}-1.82^{*} \\
(0.96)\end{array}$ & $\begin{array}{c}-2.37^{* * * *} \\
(0.84)\end{array}$ & $\begin{array}{c}-2.02^{* *} \\
(0.99)\end{array}$ \\
\hline Observations & 1658 & 1325 & 1658 & 1323 & 1658 & 1323 \\
\hline
\end{tabular}

Marginal effects; Standard errors in parentheses

${ }^{*} p<0.10,{ }^{* *} p<0.05,{ }^{* * *} p<0.01$ 
Table 11: Probability of Homeownership - Model B

Recent Movers - Marginal effects

8oth Percentile of the HPI Distribution

\begin{tabular}{|c|c|c|c|c|c|c|}
\hline \multirow{2}{*}{ MODELS } & \multicolumn{2}{|c|}{ Model B1 } & \multicolumn{2}{|c|}{ Model B2 } & \multicolumn{2}{|c|}{ Model B3 } \\
\hline & 2003 & 2007 & 2003 & 2007 & 2003 & 2007 \\
\hline Log Income & $\begin{array}{c}0.07^{* * *} \\
(0.01)\end{array}$ & $\begin{array}{l}0.04^{* *} \\
(0.02)\end{array}$ & $\begin{array}{c}0.08^{* * *} \\
(0.01)\end{array}$ & $\begin{array}{l}0.04^{* *} \\
(0.02)\end{array}$ & $\begin{array}{c}0.08^{* * *} \\
(0.02)\end{array}$ & $\begin{array}{c}0.05^{* * *} \\
(0.02)\end{array}$ \\
\hline Income Constr*incr HPI & $\begin{array}{c}-0.15^{* * *} \\
(0.04)\end{array}$ & $\begin{array}{l}-0.01 \\
(0.06)\end{array}$ & $\begin{array}{l}-0.06 \\
(0.05)\end{array}$ & $\begin{array}{c}0.00 \\
(0.07)\end{array}$ & $\begin{array}{c}-0.08^{* *} \\
(0.04)\end{array}$ & $\begin{array}{c}0.04 \\
(0.06)\end{array}$ \\
\hline ncome Constr*non-incr HPI & $\begin{array}{c}-0.09^{* *} \\
(0.04)\end{array}$ & $\begin{array}{c}0.00 \\
(0.04)\end{array}$ & $\begin{array}{c}-0.09^{* *} \\
(0.04)\end{array}$ & $\begin{array}{c}0.00 \\
(0.05)\end{array}$ & $\begin{array}{l}-0.06^{*} \\
(0.04)\end{array}$ & $\begin{array}{c}0.03 \\
(0.04)\end{array}$ \\
\hline Wealth Constr*incr HPI & $\begin{array}{c}-0.37^{* * *} \\
(0.04)\end{array}$ & $\begin{array}{c}-0.29^{* * *} \\
(0.04)\end{array}$ & $\begin{array}{c}-0.37^{* * *} \\
(0.04)\end{array}$ & $\begin{array}{c}-0.29^{* * *} \\
(0.05)\end{array}$ & $\begin{array}{c}-0.37^{* * *} \\
(0.04)\end{array}$ & $\begin{array}{c}-0.29^{* * *} \\
(0.05)\end{array}$ \\
\hline Wealth Constr*non-incr HPI & $\begin{array}{c}-0.39^{* * *} \\
(0.03)\end{array}$ & $\begin{array}{c}-0.37^{* * *} \\
(0.04)\end{array}$ & $\begin{array}{c}-0.39^{* * *} \\
(0.03)\end{array}$ & $\begin{array}{c}-0.37^{* * *} \\
(0.04)\end{array}$ & $\begin{array}{c}-0.39^{* * *} \\
(0.03)\end{array}$ & $\begin{array}{c}-0.36^{* * *} \\
(0.04)\end{array}$ \\
\hline Credit Constr*incr HPI & $\begin{array}{l}-0.01 \\
(0.04)\end{array}$ & $\begin{array}{l}-0.04 \\
(0.06)\end{array}$ & $\begin{array}{c}0.00 \\
(0.04)\end{array}$ & $\begin{array}{l}-0.04 \\
(0.06)\end{array}$ & $\begin{array}{l}-0.01 \\
(0.04)\end{array}$ & $\begin{array}{l}-0.04 \\
(0.06)\end{array}$ \\
\hline Credit Constr*non-incr HPI & $\begin{array}{c}-0.12^{* * *} \\
(0.03)\end{array}$ & $\begin{array}{l}-0.04 \\
(0.03)\end{array}$ & $\begin{array}{c}-0.12^{* * *} \\
(0.03)\end{array}$ & $\begin{array}{l}-0.04 \\
(0.03)\end{array}$ & $\begin{array}{c}-0.11^{* * *} \\
(0.03)\end{array}$ & $\begin{array}{l}-0.05 \\
(0.03)\end{array}$ \\
\hline Change HPI & & & $\begin{array}{c}-0.41^{* *} \\
(0.18)\end{array}$ & $\begin{array}{c}-0.06 \\
(0.13)\end{array}$ & & \\
\hline Value to Rent & & & & & $\begin{array}{c}-0.59^{* * *} \\
(0.17)\end{array}$ & $\begin{array}{c}-0.71^{* * *} \\
(0.16)\end{array}$ \\
\hline Married & $\begin{array}{l}0.07^{* *} \\
(0.03)\end{array}$ & $\begin{array}{c}0.14^{* * *} \\
(0.04)\end{array}$ & $\begin{array}{c}0.08^{* * *} \\
(0.03)\end{array}$ & $\begin{array}{c}0.14^{* * *} \\
(0.04)\end{array}$ & $\begin{array}{c}0.08^{* * *} \\
(0.03)\end{array}$ & $\begin{array}{c}0.15^{* * *} \\
(0.04)\end{array}$ \\
\hline Black & $\begin{array}{c}-0.07^{* * *} \\
(0.02)\end{array}$ & $\begin{array}{c}-0.13^{* * *} \\
(0.03)\end{array}$ & $\begin{array}{c}-0.07^{* * *} \\
(0.02)\end{array}$ & $\begin{array}{c}-0.13^{* * *} \\
(0.03)\end{array}$ & $\begin{array}{c}-0.08^{* * *} \\
(0.02)\end{array}$ & $\begin{array}{c}-0.14^{* * *} \\
(0.03)\end{array}$ \\
\hline Hispanic & $\begin{array}{c}0.01 \\
(0.03)\end{array}$ & $\begin{array}{c}-0.06^{*} \\
(0.03)\end{array}$ & $\begin{array}{c}0.02 \\
(0.03)\end{array}$ & $\begin{array}{l}-0.06^{*} \\
(0.03)\end{array}$ & $\begin{array}{c}0.01 \\
(0.03)\end{array}$ & $\begin{array}{l}-0.04 \\
(0.03)\end{array}$ \\
\hline Log Grade Attained & $\begin{array}{l}-0.07 \\
(0.06)\end{array}$ & $\begin{array}{c}0.02 \\
(0.08)\end{array}$ & $\begin{array}{l}-0.07 \\
(0.06)\end{array}$ & $\begin{array}{c}0.03 \\
(0.08)\end{array}$ & $\begin{array}{l}-0.05 \\
(0.06)\end{array}$ & $\begin{array}{c}0.04 \\
(0.07)\end{array}$ \\
\hline Kids & $\begin{array}{c}0.09^{* * * *} \\
(0.02)\end{array}$ & $\begin{array}{c}0.03 \\
(0.03)\end{array}$ & $\begin{array}{c}0.09^{* * *} \\
(0.02) \\
\end{array}$ & $\begin{array}{c}0.03 \\
(0.03)\end{array}$ & $\begin{array}{c}0.09^{* * *} \\
(0.02)\end{array}$ & $\begin{array}{c}0.03 \\
(0.03)\end{array}$ \\
\hline Observations & 1658 & 1325 & 1658 & 1323 & 1658 & 1323 \\
\hline
\end{tabular}

Marginal effects; Standard errors in parentheses

${ }^{*} p<0.10,{ }^{* *} p<0.05,{ }^{* * *} p<0.01$ 